\title{
The Pleasant and the Useful: Pilgrimage and Tourism in Habsburg Mariazell
}

\section{Citation}

Frank, Alison. 2009. The pleasant and the useful: pilgrimage and tourism in Habsburg Mariazell. Austrian History Yearbook 40:157-182.

\section{Published Version}

doi:10.1017/S0067237809000149

\section{Permanent link}

http://nrs.harvard.edu/urn-3:HUL.InstRepos:10611804

\section{Terms of Use}

This article was downloaded from Harvard University's DASH repository, and is made available under the terms and conditions applicable to Other Posted Material, as set forth at http:// nrs.harvard.edu/urn-3:HUL.InstRepos:dash.current.terms-of-use\#LAA

\section{Share Your Story}

The Harvard community has made this article openly available.

Please share how this access benefits you. Submit a story.

\section{Accessibility}




\title{
The Pleasant and the Useful: Pilgrimage and Tourism in Habsburg Mariazell
}

\author{
Alison Frank
}

$\mathrm{T}$

He idea behind this ARTiCle came from a riddle. A 1907 guidebook to the Austro-Hungarian pilgrimage site of Mariazell carried the following enigmatic line: "The traveler who, while visiting Mariazell, wishes to combine the pleasant and the useful-for whom the pilgrimage should be at the same time an excursion into the mountains-will find a series of pretty promenades that lead him only a short way out of town and require absolutely no exertion." ${ }^{1}$ The author most likely thought the meaning of this somewhat banal passage was completely clear. But the historian must wonder what exactly was "pleasant" and what was "useful" for the traveler to Mariazell. Was it pleasant to contemplate the majesty of God and the clemency of the Virgin Mary and useful to exercise one's body in the fresh, mountain air-even without exertion? Or was it useful to demonstrate one's piety and devotion via pilgrimage and dutiful time spent in mass, but pleasant to stroll through the temple of nature, admiring local flora and fauna along the way? Both of these interpretations are as truthful as they are possible, and their coexistence exemplifies a quintessential duality of religious tourism in the nineteenth century. Mariazell was both a "place of mercy" (Gnadenort), and an "alpine pearl"; its attraction stemmed from a hybrid of sanctity and sanctuary that was exploited by the citizens and residents of Mariazell whose livelihood depended on attracting a constant flow of outsiders. ${ }^{2}$

Even before William Wordsworth and Percy Blythe Shelley made the mountains the subject of lyric poetry, J. M. W. Turner captured them in oil, and John Ruskin called them "the cathedrals of the earth" and "the beginning and the end of all natural scenery," the beauty of the Alps had been described in quasi-religious terms: its valleys "a Paradise amidst the Wildness of those cold hoary landskips which lay about it."3 Crosses erected on mountain summits in the nineteenth and

\footnotetext{
${ }^{1}$ Hans Rögl, Maria-Zell: Geschichte und Beschreibung des berühmten Wallfahrtsortes, der Kirche, Schatzkammer, etc., mit einem Führer durch Maria-Zell und Umgebung und einem Beitrage des nied.-öst. Landes-Eisenbahnamtes über die Maria-Zeller Bahn mit vielen Illustrationen und einem belletristischen Anhange (Mariazell, 1907), 206.

${ }^{2}$ Alpine pearl (Alpenperle) from Karl Muckenschnabl, Nied.österreichisch-steirische Alpenbahn St. Pölten-MariaZell. Illustrierter Führer. 3rd ed. (St. Pölten, 1908), 4.

${ }^{3}$ John Ruskin, Sesame and Lilies: Two Lectures delivered at Manchester in 1864 (New York, 1865), 53; John Ruskin, Modern Painters, vol. 4 (Boston, 1875), 427; Joseph Addison, Tatler, no. 161 (20 April 1710), as cited in Simon Schama, Landscape and Memory (New York, 1996), 478. Marjorie Hope Nicolson's pioneering work Mountain Gloom, Mountain Glory described a gradual transition in literary images of the Alps, which, until the very end of
} 
twentieth centuries marked them both as close to God, and, specifically, as Christian spaces. ${ }^{4}$ The Alps were a place where religiosity and tourism met to celebrate the sublime. This complementary relationship did not, however, emerge automatically. On the contrary, it required a great deal of concentrated effort on the part of the Alpine communities that prospered from the increased attention that came with burgeoning tourism. In Mariazell, this effort was directed both at transforming the small town into a comfortable and welcoming destination for tourists and at preserving the sanctity that came from centuries of Marian devotion.

Across Europe, the tribulations of the revolutionary and Napoleonic wars were followed by a gradual resurgence of popular religiosity, which took off after $1850 .{ }^{5}$ This religious revival was not marked so much by the resurrection of old traditions lost during the preceding decades as by the creation of new traditions suited to new times. One of the most striking changes was the centrality of Marian apparitions. Along with the change in sacred visions came changes in the visionaries themselves, with children outnumbering adults and females outnumbering males. The emphasis on Mary even affected the dates of pilgrimage, which clustered around Marian holidays, particularly those in summer months. ${ }^{6}$ The declaration of the doctrine of immaculate conception in 1854 strengthened the enthusiasm for Marian worship. A vigorously conservative political climate encouraged the church to change the organization and leadership of pilgrimage, increasingly eliminating the spontaneity and unpredictability that had become associated with the potential for mob violence during the revolutionary years $1848 / 1849 .^{7}$ New-style pilgrimage sites were highly devotional and marked by fervent

the seventeenth century, were seen as ugly, intimidating, and forbidding (Simon Schama said they were "spectacles of holy Terror, "449) and then, over the course of the eighteenth century, became inviting, picturesque, and beautiful (Marjorie Hope Nicolson, Mountain Gloom, Mountain Glory: The Development of the Aesthetics of the Infinite [Ithaca, 1959]). Andrew Beattie's highly entertaining popular history, The Alps: A Cultural History, contains sections on romantic poets Wordsworth, Shelley, and Byron, art critic John Ruskin and his support of J. M. W. Turner, and other Alpine enthusiasts. Andrew Beattie, The Alps: A Cultural History (Oxford, 2006), 120-40.

${ }^{4}$ The gradual process of erecting crosses atop nearly every Austrian summit is a fascinating one that deserves further study in its own right. Although some prominent peaks received ceremonial crosses in the earliest years of the nineteenth century-including the Großglockner and the Erzberg (Alois Egger, "Geschichte der Glocknerfahrten," Jahrbuch des Oesterreichischen Alpen-Vereines [Vienna, 1865]: 40, 44, 54)-as late as the 1860s, hikers were as likely to find a heap of stones or a modest pyramid upon reaching a summit as a cross. "Ersteigung der Hochalmspitze durch Ed. v. Mojsisovics" and "Der Glocknergipfel im August 1861," Mittheilungen des österreichischen Alpen-Vereines (Vienna, 1863), 290-92, 305; K. Reissacher, "Der Rathhauskogel und Kreuzkogel in der Gastein," Mittheilungen des Österreichischen Alpen-Vereines (Vienna, 1864), 209. Today, the ubiquity of summit crosses is so profound that their absence suggests one has not yet reached the "real" summit.

${ }^{5}$ Peter Leisching, "Die Römisch-Katholische Kirche in Cisleithanien," in Die Habsburgermonarchie 1848-1918, vol. 4, Die Konfessionen, 2nd ed. (Vienna, 1995), 134; Jonathan Sperber, Popular Catholicism in Nineteenth Century Germany (Princeton, NJ, 1984), 55. Both Adam Bunnell and Peter Leisching link an increase in religious enthusiasm to post-Kantian romanticism. Leisching, 156-57; Adam Bunnell, Before Infallibility: Liberal Catholicism in Biedermeier Vienna (Rutherford, NJ, 1990), 21, 23. William Bowman notes that this revival was not uniformly pronounced: in Vienna, popular religiosity does not appear to have increased markedly "in the period before 1870." William Bowman, Priest and Parish in Vienna, 1780-1880 (Boston, 1999), 10, 17. Laurence Cole dates the Catholic revivalist movement in Austria back to the 1820s, while noting that the Concordat of 1855 "placed the church in a vastly more privileged position than pre-1848." Laurence Cole, “The Counter-Reformation's Last Stand: Austria," in Culture Wars: Secular-Catholic Conflict in Nineteenth-Century Europe, ed. by Christopher Clark and Wolfram Kaiser (Cambridge, 2003), 287, 289.

${ }^{6}$ David Blackbourn, Marpingen: Apparitions of the Virgin Mary in Nineteenth-Century Germany (New York, 1994), 4; Sperber, Popular Catholicism, 65; Mary Lee Nolan and Sidney Nolan, Christian Pilgrimage in Modern Western Europe (Chapel Hill, NC, 1989), 56.

${ }^{7}$ Sperber, Popular Catholicism, 71. In a striking example of the widespread acknowledgment of religious rituals' political significance, revolutionaries had infiltrated two Viennese Corpus Christi processions, substituting a 
personal piety in opposition to the secularized post-Darwinian world; yet these sites were also indebted to modern technology and transportation. Mary represented to the pious who felt trapped in a secular world the hope that the sacred had not abandoned them. ${ }^{8}$

This resurgence in pilgrimage took place not only in the context of an industrializing European economy, but also in an age of widespread interest in and access to tourism. Both the pilgrim and the tourist were travelers; and although church authorities insisted that their pursuits were not comparable, it became increasingly difficult to distinguish neatly between them. Anthropologists Victor and Edith Turner have noted that in contemporary society, "a tourist is half pilgrim, if a pilgrim is half a tourist. Even when people bury themselves in anonymous crowds on beaches, they are seeking an almost sacred, often symbolic, mode of communitas." Tourists and pilgrims have in common a desire to escape their normal cultural state and enter into a stage of liminality in which the ritual subject wanders between familiar lines of classification. ${ }^{10}$ This need not in any way diminish the profoundly sacred character of pilgrimage or pilgrimage destinations to the faithful. As historian of Lourdes Suzanne Kaufman has written, pilgrims "searched for tangible proof of God's presence by touching the physical site, looking at relics, collecting artifacts, and buying souvenirs. As clerics and lay believers alike sought ways to interact with God, they ... commingled the spiritual and the material, the commercial and the religious." ${ }^{11}$ This transitional state of being can be reproduced in the physical location of the pilgrimage site, often situated on the margins of traditional geographical, conceptual, or political divides.

Although pilgrimage can transcend boundaries, it can also be strengthened by them. According to anthropologist William Christian, Jr., "the more clear-cut the sociographic unit, the sharper its boundaries, then the more likely it was to have a cultural symbol, a protector, a patron in a shrine image."12 Although marginality was an important characteristic of pilgrimage (and more specifically of apparition) sites, pilgrimage was also gradually absorbed into mainstream church practice. Increasing pressure from church authorities concentrated attention on a few major sites, at the cost of smaller, local ones, and simultaneously imposed routines and institutional underpinnings on pilgrimage that may have changed the nature of the liminal experience of pilgrims.

In the late eighteenth century, the Austrian state (with some church support) tried, with mixed results, to suppress pilgrimage. ${ }^{13}$ Although state-initiated church reforms, such as

prominent Jewish physician in one case and a Protestant leader of the national guard in the other, in the position traditionally held by the emperor. Bowman, Priest and Parish, 199-200.

${ }^{8}$ Victor Turner and Edith Turner, Image and Pilgrimage in Christian Culture (New York, 1978), 19; William Christian, Jr., Person and God in a Spanish Valley, 2nd. ed. (Princeton, NJ, 1972), 99.

${ }^{9}$ Turner and Turner, Image and Pilgrimage, 20. The connection between pilgrimage and tourism supports Rudy Koshar's argument that "leisure practices have very long temporal reaches" even while they "describe important transformations over time." Rudy Koshar, "Seeing, Traveling, and Consuming: An Introduction," in Histories of Leisure, ed. Rudy Koshar (Oxford and New York, 2002), 4. József Böröcz’s listing of "all the historical travel types” includes "the explorer and the pilgrim, the monk, the merchant, the student, the refugee, the missionary, the hermit, the water and mountain cure seeker or, on the more sinister side, the smuggler, and even the conqueror with his Golden Hordes." József Böröcz, “Travel-Capitalism: The Structure of Europe and the Advent of the Tourist," Comparative Studies in Society and History 34, no. 4 (October 1992): 711-12.

${ }^{10}$ Turner and Turner, Image and Pilgrimage, 6.

${ }^{11}$ Suzanne K. Kaufman, Consuming Visions: Mass Culture and the Lourdes Shrine (Ithaca, NY, 2005), 11.

${ }^{12}$ Christian, Person and God, 99.

${ }^{13}$ Bowman, Priest and Parish, 2. Contempt for pilgrimage made its way into the training of new priests. In a handbook of pastoral theology that was published in multiple editions, Franz Giftschütz, professor of pastoral theology at the University of Vienna from 1778 to 1788, suggested that priests "warn against the excessive trust 
those under Joseph II of Austria, have been framed as conflicts between the church and state, there were voices within the church that welcomed-and spearheaded-the modification of traditional practices. ${ }^{14}$ Turner and Turner describe the result of such intervention: the "voluntaristic, even miraculous, essence" of pilgrimage was "subjugated to doctrinal and organizational edict." ${ }^{5}$ Particularly under Francis II/I and his successors, the church approached the combined threat from unruly pilgrims and suspicious secular administrators not by eliminating pilgrimage, but by taking control of it. ${ }^{16}$

The study of nineteenth-century pilgrimage reveals the changing relations between church and state, beginning with the state's encroachment upon both the church's material wealth and its role in ordering people's lives through the introduction of secular rites of passage. ${ }^{17}$ Examining pilgrimage can expose the lines along which liberal anticlerics and conservative Catholics divided the world into those who understand (reason or faith) and those who are misguided (by superstition or worldly concerns). Connecting pilgrimage practices to mass consumption, as Suzanne Kaufman has done, brings forth nineteenth-century debates about the lines dividing the sacred from the secular. ${ }^{18}$ By including the natural environment and ways in which religious authorities and local entrepeneurs tried to harness its spiritual and touristic potential, the study of pilgrimage can also reveal the growing attention to and

that some place in pilgrimage." Franz Giftschütz, Leitfaden der in den k.k. Erblanden vorgeschriebenen deutschen Vorlesungen über die Pastoraltheologie, 4th ed. (Graz, 1801), 363. Josef Johann Pehem, who taught canon law at the University of Vienna from 1779 to 1799, agreed that pilgrimages were, in the words of William Bowman, "unnecessary accretions to Catholic religious culture." Bowman, Priest and Parish, 121.

${ }^{14}$ Karl Vocelka attributes a split in the historiography between defenders and opponents of Joseph II's reforms to "two fundamentally incompatible worldviews." The Marxist historian Eduard Winter defended Joseph II's variant of reform Catholicism as positive for the church. On the other hand, Josephinian logic was "foreign" to the Jesuit historian Ferdinand Maaß. See Karl Vocelka, Verfassung oder Konkordat? Der publizistische und politische Kampf der österreichischen Liberalen um die Religionsgesetze des Jahre 1868 (Vienna, 1978), 21.

${ }^{15}$ Turner and Turner, Image and Pilgrimage, 31-32. The "clear tendency of the Baroque church and of Catholic princes to regard pilgrimage as a barometer of religious orthodoxy and political loyalty" has inspired David Luebke to analyze the political symbolism of group pilgrimage in the early modern period. David Luebke, "Naïve Monarchism and Marian Veneration in Early Modern Germany," Past and Present 154 (February 1997):76.

${ }^{16}$ Peter Leisching notes that "By tying itself to old devotions, the [post-1848] Church hoped to stabilize the consciousness and churchly piety of a population stuck in a traditional mentality vis-à-vis anticlerical social processes," and that this desire led to a "politicization of the cult of saints" in the nineteenth century. Leisching, "Die Römisch-Katholische Kirche," 134. On Lower Austria (including Vienna), see Bowman, Priest and Parish, 215. For non-Habsburg German lands, see Sperber, 96. James Van Horn Melton sees in Maria Theresa's education reforms of the 1770s a sign of the monarchy and church's combined mission to "regulate popular culture" while directing it away from "theatrical, ritualistic, and nonliterary media," including pilgrimage. James Van Horn Melton, "From Image to Word: Cultural Reform and the Rise of Literate Culture in Eighteenth-Century Austria," The Journal of Modern History 58, no. 1 (March 1986): 97-98.

${ }^{17}$ This is not, however, to suggest that a trend towards secularization continued uninterrupted over the course of the nineteenth century. Karl Vocelka notes that, although Liberals would take Joseph II as their figurehead decades later, Josephinian decrees were by no means "liberal reforms." Moreover, the Concordat reached between the Austrian crown and the Apostolic See in 1855, gave the church "a dangerously strong position, on equal footing [with the state] in the internal structure of the Habsburg monarchy, that extended far beyond its function as a linchpin of neoabsolutism." Vocelka, Verfassung oder Konkordat?, 23, 28. Even those within the church who would not characterize their position as "dangerous" greeted the Concordat as "exceeding all expectations." For responses to the Concordat within Austria, see Gottfried Mayer, Österreich als katholisches Grossmacht: Ein Traum zwischen Revolution und liberaler Ära (Vienna, 1989), 207-10. For more on the Concordat in general, see Erika Weinzierl, Die österreichischen Konkordate von 1855 und 1933 (Vienna, 1960).

${ }^{18}$ Suzanne K. Kaufman, "Selling Lourdes: Pilgrimage, Tourism, and the Mass-Marketing of the Sacred in Nineteenth-Century France," in Being Elsewhere: Tourism, Consumer Culture, and Identity in Modern Europe and North America (Ann Arbor, 2001), 65. 
admiration of certain kinds of physical space, as the location of pilgrimage contributed to its sanctity, and the Alpinists' worship of nature began to enter the mainstream. And it can help characterize transformations in the sense of community, as it moved between groups defined locally, regionally, and confessionally.

Mariazell is located in the eastern Alps, about 140 kilometers (85 miles) southwest of Vienna and just over the Styrian side of Lower Austria's border. A flourishing medieval shrine, its popularity peaked in the eighteenth century, at the very moment of transition from medieval to modern pilgrimage. ${ }^{19}$ In the modern period, however, Mariazell had to withstand not only pressure from the state, but also the competition of newer apparition shrines elsewhere.

Despite claims that Mariazell's foundation is "encircled in an impenetrable darkness," scholars have generally agreed that its history begins with a papal letter written by Hadrian IV (1154-1158), granting permission to St. Lambrecht's, one of the most powerful abbeys in Upper Styria, to send five monks out on a civilizing mission. ${ }^{20}$ One of the missionary priests sent out to the Alpine wilderness built a wooden chapel at the present location of Mariazell. Given the brevity of Hadrian IV's papal tenure, scholars have agreed to fix Mariazell's foundation in 1157, a date well established in popular belief by the beginning of the seventeenth century. ${ }^{21}$ Over the centuries, its story has been embellished with miracles. When the monk (who at some point in his travels through the public imagination took on the name Magnus) found his path blocked by a huge boulder, he placed within a nook the small wooden statue of Mary and her infant son that he had brought with him on his journey. The monk then prayed to Mary to intercede on his behalf so that he could continue to his destination. The boulder, it is told, then split in half, and not far off Magnus built a small chapel (Zell) for himself and the statue. ${ }^{22}$ The prominence of the boulder itself in this tale is an important reminder that the link between sacred space and natural physical markers was not invented in the nineteenth century, although it is strongly present in the modern period. According to historian Derek Beales, in the eighteenth century, the number and variety of pilgrimage sites increased as "tree, rock, spring, hill, and cave were brought into relation with the Catholic faith." ${ }^{\text {23 }}$

The first notable travelers who were attracted to the spot on which Magnus had built his Marian "cell" because of its status as a holy place were Margrave Vladislaus Henry of

\footnotetext{
${ }^{19} \mathrm{~A}$ transition that belies the notion of the early modern period as representing a " 300 -year lull in shrine formation or pilgrimage activity." Nolan and Nolan, Christian Pilgrimage, 273. This point is further demonstrated by Anna Coreth's study of Habsburg piety in the early modern period. Anna Coreth, Pietas Austriaca, trans. William D. Bowman and Anna Maria Leitgeb (West Lafayette, IN, 2004). Derek Beales suggests that the peak of the Catholic Reform came "as late as the mid-eighteenth century." Derek Beales, Prosperity and Plunder: European Catholic Monasteries in the Age of Revolution, 1650-1815 (Cambridge, 2003), 29.

${ }^{20}$ Quotation from P. Othmar Wonisch OSB, "Die Mariazeller Ursprungslegende," in Hanns Koren and Leopold Kretzenbacher, eds., Volk und Heimat: Festschrift für Viktor von Geramb (Graz, Salzburg, Vienna, 1949), 167.

${ }^{21}$ The oldest extant printed sources recounting the legend of Mariazell's founding come from the year 1604 and present 1157 as an undisputed date of foundation. Wonisch, "Ursprungslegende," 167-78.

${ }^{22}$ Some version of this legend appears in all accounts of the history of Mariazell. For an analysis of its development and an interpretation of its potential symbolism (the monk represents St. Lambrecht's, the boulder in his path represents the obstacles facing the abbey before it can develop the land and build churches and parishes in the region), see Wonisch, "Ursprungslegende." Wonisch further points out that the papal letter was dated St. Thomas' Day, now celebrated as the date of Magnus' arrival (Wonisch, 176, n. 9). Magnus' statue, carved out of linden wood, remains on display in the church's Gnadenaltar to this day.

${ }^{23}$ Beales, Prosperity and Plunder, 29.
} 
Moravia and his wife. ${ }^{24}$ The couple came to Mariazell around 1200, after a long and nearly fatal illness, in gratitude for Mary's intercession on their behalf. They reputedly ordered construction begun on a stone chapel to replace the wooden structure they found at the site. The story of their illness, recovery, pilgrimage, and benefaction makes up the second miraculous legend of Mariazell. Mariazell's alleged effectiveness in curing and preventing physical maladies ranging from illness to infertility became one of the most enduring attributes of pilgrimage there. $^{25}$

The third miracle legend also revolves around the patronage of a distant monarch. In or about 1364, King Louis I of Hungary found himself at the head of an army of 20,000 soldiers facing an enemy of 80,000 "wild barbarians" and prayed to Mary for assistance. ${ }^{26}$ According to legend, he awoke in the morning to find a picture of Mary lying on his chest. Carrying the picture into battle, he proceeded to defeat the enemy. In gratitude he made a pilgrimage to Mariazell and had a church built around the small chapel (in addition to donating art, bridal clothing, equestrian accessories, and other treasures that became the core of the church's treasury). ${ }^{27}$

These foundational legends did more than establish the origins of Mariazell's sacred character. William Bowman has noted that they embody three of Mariazell's most important claims to lying at the center of the Habsburg Empire's spiritual character: its ability to serve as a source of strength in "times of confessional conflict or stress"; its ability to guarantee the health and fertility of not only the monarchs and their families, but also their subjects; and its ability to support the physical defense of the dynasty's Catholic territory. ${ }^{28}$ Taken together, the trinity of a Styrian missionary, a pair of margravely Bohemian convalescents, and a Hungarian warrior-king also firmly established Mariazell's supranational status. Not only by virtue of the intended universality of Roman Catholicism, but also by virtue of the political heritage of its earliest patrons, Mariazell, like the dynasty it came to serve, had no choice but to reach beyond putatively national categories.

\footnotetext{
${ }^{24}$ Vladislaus III Henry served briefly as duke of Bohemia (from June until December 1197) before abdicating in favor of his older brother, Přemysl Otakar, and accepting the margravate of Moravia in exchange. His wife often appears as Agnes or Kunegunde in popular histories of Mariazell.

${ }^{25}$ Both Maria Theresa and her father, Charles VI, made pilgrimages to Mariazell in an attempt to influence their (and their spouses') fertility through prayer. On the perceived link between piety and reproduction, see Derek Beales, Joseph II: In the Shadow of Maria Theresa, 1741-1780 (Cambridge, 1987), 21.

${ }^{26}$ According to William Bowman, these "wild barbarians," also commonly called "Turks," were most likely Bulgarian Muslims. William Bowman, "The State, Popular Religion, and Political Power: Pilgrimages and Religious Practices at Mariazell, Austria," paper given at the German Studies Association Conference, San Diego, CA, 6 October 2007.

${ }^{27}$ In his admirable attempt to investigate the historical accuracy of all three legends, Helmut Eberhart calls into question both the nature of the church expansion ordered by Louis and also the true origin of several of the donated objects attributed to him. Eberhart, "Geschichte und Bedeutung Mariazells als Wallfahrtsort," in Mariazell und Ungarn: 650 Jahre religiöse Gemeinsamkeit, vol. 30 of Veröffentlichungen des Steiermärkischen Landesarchivs (Graz, 2003), 30-35.

${ }^{28}$ Bowman, "The State, Popular Religion, and Political Power." Details of all three of the foundational miracles can be found in Othmar Wonisch, Mariazell, 2nd ed. (Munich and Zürich: Schnell and Steiner, 1980), 3-4, and Paul Bussard, Our Lady of Mariazell (St. Paul, MN, 1958), 19-21. The enduring significance of pilgrimage in times of war became a prominent theme during the First World War. Cardinal Friedrich Gustav Piffl held a speech in Mariazell on 1 April 1916, in which he noted that all of the monarchy's rulers had "begged in difficult times of war the generalissima, the highest warrior-queen to invoke victory and peace for the threatened empire before her holy son." "Ansprache Sr. Eminenz des Kardinals Gustav Piffl in Maria-Zell," 1 April 1916. Stiftsarchiv St. Lambrecht (SAStL), Karton: Nachläße.
} 
Along with foreign monarchs, the Habsburgs also singled out Mariazell for particular favor. Albert II of Austria elevated the village growing around the church to the status of market town in 1342, and the honors bestowed on Mariazell by members of the ruling dynasty increased over the next several centuries. ${ }^{29}$ Mariazell's reputation was augmented not only by royal favor, but also by the attention it received from the pope. In 1399, Pope Boniface IX jolted Mariazell out of obscurity by granting the first plenary indulgence directed at pilgrims to Mariazell, matched only by a similar indulgence for pilgrims to St. Mark's in Venice. ${ }^{30}$ The indulgence remained in effect until 1567 (the height of religious strife in Styria), and Mariazell's popularity continued to grow. ${ }^{31}$ By 1689 , Mariazell was able to attract 61,000 pilgrims annually, which rose to 104,000 in 1692 and to 120,000 at the beginning of the eighteenth century. ${ }^{32}$

Mariazell enjoyed all the glory of a Reichsheiligtum during the reigns of Leopold I and Maria Theresa, attracting 188,000 pilgrims in 1725 and reaching its pilgrimage zenith in 1757 during its sexcentennial celebrations. In this year alone, 373,000 communion wafers were distributed. ${ }^{33}$ The period of Mariazell's greatest popularity coincided with the period of greatest prosperity for its mother monastery, St. Lambrecht, the "richest monastery in Styria." 44 After subtracting its debts, St. Lambrecht's assets were estimated, at the time of an inventory in the 1780 s, to be $1,787,483$ florins. The monastery's possessions included the domain of St. Lambrecht itself, with dairy farms, forests, privileges, and tithes in the value of 394,182 florins; the domain of Zell, with dairies, forests, fisheries, mills, charcoal-burneries, foundries, cast-iron works, vineyards, and a large provost's dwelling in the value of 895,760 florins; and many other properties. ${ }^{35}$ But this prosperity was not to last. The last decade of the eighteenth and first decades of the nineteenth centuries brought with them a series of disasters for St. Lambrecht and Mariazell, beginning but not ending with Josephinian reforms. St. Lambrecht's was suppressed in 1786, and its holdings were sold or transferred to universities and other secular institutions. ${ }^{36}$

\footnotetext{
${ }^{29}$ Volker Press credits Ferdinand II with tightly interweaving imperial politics with religiosity, setting a precedent of Habsburg pilgrimage to Mariazell specifically, but also, more broadly of the dynasty's Catholic piety. Volker Press, "The Habsburg Court as Center of the Imperial Government," The Journal of Modern History 58, Supplement: Politics and Society in the Holy Roman Empire, 1500-1806 (December 1986): 540.

${ }^{30}$ Immaculata Waid, Mariazell und das Zellertal aus Geschichte und Chronik (St. Pölten, 1982), 63. According to Marian Sterz, the indulgence was granted in 1400, not 1399. Marian Sterz, Grundriß einer Geschichte der Entstehung und Vergrößerung der Kirche und des Ortes Maria-Zell (Vienna, 1819).

${ }^{31}$ Waid, Mariazell, 110.

${ }^{32} 1689$ and 1692: Ludwig Hüttl, Marianische Wallfahrten im süddeutsch-österreichischen Raum: Analysen von der Reformations- bis zur Aufklärungsepoche (Vienna, Cologne, 1985), 48. Early 18th c.: Rögl, Maria-Zell, 29. Here, as elsewhere in the text, the number of visiting pilgrims is estimated by the number of communion wafers distributedan admittedly imperfect indicator of traffic.

${ }^{33} 1725$ : Hüttl, 48; 1757 communion wafers: Sterz, Grundriß, 84. This was, of course, a "logistical masterpiece of the first order," in the words of an anonymous reviewer of this article. Its implications for the town of Mariazell are discussed below. The practice of bivouacking in the woods, although common among pilgrims in the early modern period, was not restored after the Josephinist period. Some towns near pilgrimage sites set up mass accommodations on straw beds. Georg R. Schroubek, "Die Mährer-Wallfahrt nach Maria Dreieichen," in Wallfahrten in Niederösterreich (Altenburg, [1985]), 55.

${ }^{34}$ Rögl, Maria-Zell, 31, citing P. Gabriel Schmiedbauer, "Cat. relig. perant. monast. ad S. Lamb." (Graz, 1902).

${ }^{35}$ Rögl, Maria-Zell, 33-34, again citing Schmiedbauer. This is only a partial summary of some of the many holdings and properties listed in the inventory taken in the 1780s.

${ }^{36} \mathrm{~A}$ total of 738 cloisters, which Erika Weinzierl estimates to have been about one-third of those existing in the monarchy in 1770, fell victim to Josephinian secularization. A resolution dated 29 November 1781 provides unusual insight into Joseph II's logic: "the longstanding proof that these orders are absolutely useless to others and cannot please God, prompts me to charge the cabinet to have provincial commissars mark all male and female
} 
Much of Mariazell's misfortune at the beginning of the nineteenth century has been attributed to Josephinian reform, at the same time that its success has been attributed to Theresian patronage. All literature on Mariazell emphasizes its "strong connection with ruling houses, in particular with the Habsburg dynasty." 37 Over the centuries, pilgrimages to Mariazell have made up a rite of passage for Habsburgs, whose visits and gifts constitute the greater part of any chronology of Mariazell (even Joseph II came to Mariazell at least five times). ${ }^{38}$ There is no doubt that the support of the dynasty, the so-called pietas austriaca, was critical to the development and welfare of Mariazell, beginning with its promotion to a market town in 1342. Much of Mariazell's treasury was donated by Habsburgs, and the church itself contains numerous examples of dynastic spending: silver grates and golden hearts engraved with royal monograms adorn its chapels and aisles. So, although the most striking point of connection between Mariazell and the imperial state was a point of conflict that threatened to eliminate the former entirely, this was not the only way in which the church and the state were perceived to connect, nor was their relationship defined as one in which conflict was necessary. On the contrary, at times it appeared that their interests were actually the same. As long as they shared the responsibility to look after the welfare of the empire's inhabitants, one materially and the other spiritually, their cooperation was both desirable and possible.

Joseph II, however, came to believe that pilgrimage was not "useful" but, rather, burdensome. Although the cynic might be tempted to doubt Joseph II's true motives, his enlightened distaste for pilgrimage "excess" and the dead hand of the church was genuine. Mariazell did not escape unscathed as organized pilgrimage itself was gradually eliminated. In 1772, that is, before the death of the pious Maria Theresa, pilgrimage to foreign countries was banned, along with most pilgrimages requiring an overnight stay. ${ }^{39}$ Between 1783 and 1787, first ceremonious and subsequently all pilgrimage was banned under penalty of labor, incarceration, or a fee of 30 Taler. Increasingly stark threats suggest that the initial bans were ineffective. In November of 1787 , the ban was renewed and priests were forbidden from providing help to arriving pilgrims. ${ }^{40}$ There is evidence that processions continued. In the late spring of 1789,

religious orders throughout the Erbländer that do not run a school or care for the sick or otherwise excel in studies, and take over their income and assets, as they have the Jesuits'." Erika Weinzierl, "Säkularisation und Säkularisierung," in Kirche und Staat in Idee und Geschichte des Abendlandes. Festschrift zum 70. Geburtstag von Ferdinand Maass SJ, ed. by Wilhelm Baum (Vienna \& Munich, 1973), 334. Derek Beales estimates that there were "barely 2,000 [monastic] houses" in the monarchy in the 1780s. Beales, Prosperity and Plunder, 180.

${ }^{37}$ Waid, Mariazell, 11.

${ }^{38}$ Joseph II visited in $1761,1764,1766,1767$, and 1786, the year St. Lambrecht's was suppressed(!). Hüttl, 161, citing Coreth, Pietas Austriaca (1959). See also Peter Wiesflecker, “Die Habsburger und Mariazell," in Mariazell und Ungarn, 41-53.

${ }^{39}$ Three processions from Vienna were among those spared. Hans Hollerweger, Die Reform des Gottesdienstes zur Zeit des Josephinismus in Österreich (Regensburg, 1976), 81; Waid, Mariazell, 129. Indeed, the empress also oversaw an attempt to impose significant reforms on the various religious orders, leading Eduard Winter to conclude, "The Josephinist tendency was therefore completely developed by 1772.” Der Josefinismus und seine Geschichte: Beiträge zur Geistesgeschichte Österreichs 1740-1848 (Brno, Munich, Vienna, 1943), 153. For more on the "reforms of the seventies," see also Beales, Joseph II. vol. 1:450-55. In the infamous "political testament" that she drafted in the 1750s and intended for her son and heir to read after her death, Maria Theresa strove to strike a balance between ensuring the continued prosperity of the clergy and promoting "what is useful to the public." On the difference between her likely commitment to monastic reform and Joseph's, see Beales, Prosperity and Plunder, 183-86. Nevertheless, Beales, too, concludes that the period of so-called Josephinist reforms "was well underway when she [i.e., Maria Theresa] died." Beales, Prosperity and Plunder, 179.

${ }^{40}$ There was no single "ban" on pilgrimage, but rather a series of resolutions, circulars, and decrees that outlawed various groups of processions and pilgrimages at various times of year, from various points of origin, and to various 
sixty-five pilgrims were arrested in Lambach on their way back from Mariazell. They claimed to have seen so many pilgrims coming from Vienna that they had assumed the patent forbidding pilgrimage had been abrogated. ${ }^{41}$

Nevertheless, the numbers of pilgrims to Mariazell did decline-perhaps not sharply enough to suit Joseph II, but more than enough to alarm Marian Sterz (d. 1834), a Benedictine monk who specialized in the history of the St. Lambrecht monastery. Returning again to the theme of usefulness, and even allowing utility to be defined in economic terms, Sterz decried the Josephinian reforms, calling attention to what he deemed to be their negative effect on the innocent residents of Mariazell, and, by extension, on others. It was the town and its dwellers, he argued, who were hardest hit by reforms, "When Emperor Joseph forbad the pilgrims' pageantry, their going together in hordes, and their ceremonial reception; when one took measures to hinder them in the continuation of their journey: the first hard blow struck Zell's residents." Sterz's commentary reveals little about Josephinism, but a lot about the combination of traditional religious and consumer habits that upheld Mariazell's economy. From this perspective, the greatest loss was not that pilgrims were deprived of Mariazell, but rather that Mariazell's residents were deprived of pilgrims, and hence both their livelihoods and their sense of community. Without the constant flow of outsiders, they turned against one another: "soon internal factions divided the citizens, and for some the previous good nature turned quickly into the opposite disposition." ${ }^{2}$ The flow of processions, Sterz suggests, had contributed to the sense of common Christian community in Mariazell itself.

Even centuries later, authors sympathetic to pilgrimage blame Joseph II for Mariazell's economic troubles: "the ban on pilgrimage practically robbed the population of Mariazell of its bread. Mariazell citizens attempted to petition the emperor.... They received the answer that they should earn their bread by 'spinning wool." 43 Such criticism neglects the agency of the church itself during the Josephinist period. Despite his reputation for anticlericalism, Joseph II was not himself hostile to religion or even to the Catholic Church. ${ }^{44}$ Nor did

destinations - some of them appearing merely to reiterate previous bans. For example, a decree of 11 April 1782 forbad all processions abroad; a decree dated 30 August 1783 forbad all domestic processions involving an overnight stay and all processions to Mariazell; and a 21 March 1784 circular noted that all processions and pilgrimages in the absence of a priest were forbidden. Giftschütz, Leitfaden, 361-62. Following a 1783 inquiry from the Moravian-Silesian Filialkommission, Abbot Franz Stephan Rautenstrauch (of the Benedictine monastery Braunau) recommended that the emperor ban all processions to Mariazell because they took a fortnight, during which time "häusliche Arbeit" would be neglected. Hollerweger, Reform des Gottesdienstes, 105-06, 135. The Filialkommission, subordinate to the "geistliche Hofkommission," was in charge of preparing new plans and reforms in spiritual matters. "Actenstücke zur Geschichte des österreichischen römisch-katholischen Kirchenwesens unter K. Leopold II (1790),” in Archiv für Kunde österreichischer Geschichts-Quellen 3, no. 1 (1850): 95. The difference between feierliche and stille processions was that the former were accompanied by one or more priests, and the bells were rung, and people proceeded to church as a group. Rögl, Maria-Zell, 133. According to the former archivist of St. Lambrecht's (a prolific historian of Mariazell), orders were given on 1 June 1789 to press charges against any arriving processions, confiscate their crosses and banners, and give the carriers fifty blows with a cane. To date, I have not been able to find either the original order or other mentions of it. Othmar Wonisch, Mariazeller Wallfahrtsbücher, vol. 1, Geschichte von Mariazell (Mariazell, 1947), 64.

${ }^{41}$ Hollerweger, Reform des Gottesdienstes, 194.

${ }^{42}$ Sterz, Grundriß, 86, 87.

${ }^{43}$ Waid, Mariazell, 129. For a similar story, see Liselotte Blumauer-Montenave, Zur Geschichte des Wallfahrtsortes Mariazell: Fremdenverkehr und Wallfahrt (Vienna, 1987), 20. Both authors rely heavily on the work of the prolific archivist of St. Lambrecht's and lecturer in theology at the University of Graz, Othmar Wonisch (1884-1961).

${ }^{44}$ Winter, Der Josefinismus, 128, 131. According to his biographer, Derek Beales, "it is impossible to doubt the genuineness of [Joseph's] religious fervour-which he clearly conceives to be a true Catholic's." Beales, Joseph II, vol. 1:454. 
Josephinism pit a secularizing ruler against a church unified in its opposition to his plans. On the contrary, so-called Josephinian reforms were actually the cooperative work of state agents and reform-minded representatives of the Catholic Church itself, "both of whom," in the words of historian Laurence Cole, "acknowledged the central place of the church in society as a whole." 45

During Joseph II's reign, one of the principal arguments against pilgrimage and shrines was economic and arose directly from the cameralist philosophy that characterized the Central European approach to economic thought during the Enlightenment. According to cameralists, only a comprehensive economic policy in which the state (via a corps of welltrained bureaucrats) directed public finance could guarantee general prosperity. As a corollary to this idea of a strong public administration to benefit all, the state became responsible for ensuring that its subjects were not encouraged to waste their time frivolously on activities that did not promote collective welfare. ${ }^{46}$ According to Joseph II and his advisors, only St. Lambrecht's truly benefited from pilgrimage to Mariazell, at the expense of both the state and its subjects. After all, traveling from Vienna to Mariazell and back would take the early-nineteenth-century pilgrim eight days and cost the equivalent of the monthly income of a civil servant of the ninth grade. ${ }^{47}$ Joseph II's advisor, Hofrat Franz Joseph von Heinke, portrayed pilgrimage as an economic burden that neither pilgrims nor the state could afford to bear. Not only did pilgrimage "take the peasantry away from their fieldwork and the tending of farms," but worse yet, according to Heinke, "in such pilgrimage towns, the greatest part of the time is spent not in prayer but in costly amusements." ${ }^{48}$ These amusements might have been costly to pilgrims, but they provided the lifeblood of Mariazell and other towns along popular pilgrimage routes.

Although the Austrian state did not recognize tourism as a significant source of economic activity until the late nineteenth century, there is no doubt that streams of pilgrims were an important element of the local economy along the "Via Sacra," as the road from Vienna to Mariazell was known. ${ }^{49}$ In the decades before the extension of the railroad network, the journey from Vienna to Mariazell and back lasted nine days and eight nights and involved

\footnotetext{
${ }^{45}$ Cole, “The Counter-Reformation's Last Stand," 287.

${ }^{46}$ On cameralism in Austria more generally, see Alois Brusatti, "Die Entwicklung der Wirtschaftswissenschaften und der Wirtschaftsgeschichte," in Die Habsburgermonarchie 1848-1918, vol. 1, Die wirtschaftliche Entwicklung, ed. Alois Brusatti (Vienna, 1973), 605-08. According to Eduard Winter, Joseph II, as a physiocrat, "saw that the state's only source of wealth came from the skillful cultivation of land"-a project that would be threatened by the extended absence of peasant farmers from the land they worked. Winter, Der Josephinismus, 153. Karl Vocelka sees a direct connection between "the enlightened monarch's practical, national economic motives" and restrictions on "the excrescences of Baroque piety: excessive holidays, pilgrimage, processions, confraternities, and pomp in church festivals and customs.” Vocelka, Verfassung oder Konkordat?, 22.

${ }^{47}$ Rögl, Maria-Zell, 206.

${ }^{48}$ Hofrat Heinke in his "Rechenschaftsbericht," Ferdinand Maaß, Der Josephinismus. Quellen zur seiner Geschichte in Österreich, 1760-1850, vol. 3 (Fontes Rerum Austriacarum 73), no. 10/13, 360.

${ }^{49}$ The state began measuring annual visits to important spas and sanatoria in 1876 . The annual number of guests staying in Viennese hotels was not recorded before 1874. Ferdinand Tremel, "Der Binnenhandel und seine Organisation. Der Fremdenverkehr," in Die Habsburgermonarchie 1848-1918, vol. 1, Die wirtschaftliche Entwicklung, ed. Alois Brusatti (Vienna, 1973), 395, 400. Jill Steward dates the "major expansion of tourism" in Austria to the 1880 s, but notes, "Austria's link with the modern tourist industry began with the International Exhibition of 1873 staged in Vienna." After its founding in 1896, the railway ministry supported the development of tourism by disseminating information in travel bureaus in Vienna, Innsbruck, and Graz. Jill Steward, "Tourism in Late Imperial Austria: The Development of Tourist Cultures and Their Associated Images of Place," in Being Elsewhere: Tourism, Consumer Culture, and Identity in Modern Europe and North America (Ann Arbor, 2001), 109, 110, 115.
} 
overnight stays in Aland, St. Veit, and Annaberg. ${ }^{50}$ The second largest organized pilgrimage, that from Graz to Mariazell, would stop for one night in Frohnleiten, a second night in Kapfenberg, and a third night in Seewiesen. The most significant pilgrimage from Graz left every year on 11 August, arrived in Mariazell on 14 August in time to celebrate the Feast of the Assumption, and then returned to Graz on 18 August, having sacrificed a full week to the journey. ${ }^{51}$ In 1864 , this pilgrimage alone brought 1,100 pilgrims to Mariazell and to each of the other traditional stopping places on the way. ${ }^{52}$ Although pilgrims would sometimes carry their own provisions with them, they were nevertheless dependent on innkeepers and homeowners for sleeping accommodations, beverages, and supplementary provisions. ${ }^{53}$

Alongside enlightened fears of economic waste came skepticism regarding the relationship between pilgrimage and morality. Even in the early modern period, both church and secular authorities fought constantly against insubordinate, raucous, and adulterous behavior during pilgrimages. Jonathan Sperber has noted, "processions and pilgrimages were an occasion for worldly amusement as well as religious inspiration.... Pilgrimages to distant shrines were as much worldly adventures as pious journeys, the shrines themselves as much circus sideshows as sources of devotion." ${ }^{24}$ It was, however, ultimately its alleged uselessness, rather than the pleasures associated with it, that earned pilgrimage the criticism of enlightened reformers like Heinke, who insisted that pilgrimage had been restricted under Maria Theresa in order to protect pilgrims, not attack their piety. Pilgrimage, Heinke explained, "draws the people away from their own local parish church services, promotes false devotion, causes disorder in communities and families, and leads the common man to miss his work and to spend money unnecessarily." 55 The only self-interest it served was that of pilgrimage towns and their sponsors, not of pilgrims.

In this context, the emphasis on the utility of pilgrimage in post-Josephinian literature is not surprising. The first line of defense came in the form of arguments that seemed to accept the Josephinist focus on economic welfare, but turned attention to residents of the town itself. In his 1819 account, priest and St. Lambrecht's monk Marian Sterz outlined in great detail the town's reliance on the pilgrimage trade. Its 820 residents lived in 98 houses, 44 of which were inns, which suggests that nearly half of the households were directly dependent on the tourist trade for their daily bread-more even, if one counted specialized artisans as well as innkeepers and their families. Sterz listed each of the town's artisans by trade, noting "I name the artisans in order to draw attention to the great traffic that would have to take place here such that sixty artisans could survive among a population of only $800 . " 56$

Nor did the importance of the pilgrimage trade stop at the town limits. If the pilgrims played an essential role in the economic well-being of the innkeepers, and the innkeepers together with the pilgrims played an essential role in maintaining the economic well-being of the artisans,

\footnotetext{
50“Statuten des Wiener Maria-Zeller-Prozessions-Vereines" (1861), Karton: Prozessionen, SAStL. The journey from Vienna to Mariazell is described in detail in Heinrich Adalbert Nowohrácky, ed., Jubiläums-Festblühten zur frommen Erinnerung an den Gnadenort Maria-Zell im Jahre des Heiles 1857 (Vienna and Graz, 1857), 9-34.

51"Programm der Gratzer Wallfahrt nacht Maria Zell im Jahre 1857" and "Programm der Grazer Wallfahrt nach Maria Zell im Jahre des Heils 1862,” in Karton “Mariazell: Div. Bilder u. Kleinschriften, Gebetszettel, Fotos, Plakate, Flugzettel," SAStL.

52"Wallfahrer 1864," Karton: Mariazell: Prozessionen. SAStL.

${ }^{53}$ Steward, “Tourism in Late Imperial Austria," 113.

${ }^{54}$ Sperber, Popular Catholicism, 18.

${ }^{55}$ Heinke's Vortrag of 14 August 1790, as cited in Hollerweger, Reform des Gottesdienstes, 227.

${ }^{56}$ Sterz, Grundriß, 183-85. These numbers had barely changed in 1848, when there were 108 houses, of which 44 had a liquor license.
} 
Sterz argued that the whole town contributed to the economic well-being of the empire: "The wares offered for sale here (with the exception of incense, which is made from herbs gathered in the local mountains) are gathered from various provinces of the Austrian monarchy. For example, Eger provides pictures, [Lower] Austria rosaries, Graz brass goods. Since sales here are significant, I may surely assert that there are many people in those towns who live from trade with Zell alone." 57 As a priest and a monk in St. Lambrecht's, Sterz's primary interest in Mariazell was spiritual, not economic. Nevertheless, if there had been any doubt about the town's economic dependence on pilgrimage in the eighteenth century, it was dispelled by the discomforts of the Josephinian period.

Another line of argument defended pilgrimage itself. When, in 1857, Heinrich Nowohrácky warned pilgrims that "there are indeed in our day those nonbelievers who regard pilgrimage, like every other form of worship, as ridiculous nonsense and superstition," he did not expect the pilgrims to be able to convert the nonbelievers through good behavior. He did, however, remind them, "we are embarking on a holy journey, and that a pilgrimage is a journey of penitence, not of pleasure." ${ }^{58}$ In addition to emphasizing its spiritual value, defenders of Mariazell responded to what they perceived to be attacks on the sacred rite of pilgrimage by identifying three ways in which they claimed the church could serve society more effectively than secular authorities threatening to displace it. Pilgrimage provided a source of livelihood to people that the state would be unable to replace; church institutions had demonstrably done a better job of managing funds than secular institutions; and the church could promise the orderly behavior of even large masses of people, inspired by its message and its authority to respect church and state alike. Like Christoph Moufang, an ultramontane Catholic seminar regent in Mainz, who argued in the 1850s, "the priest can do more than the police," they emphasized the common cause of institutions promoting discipline. ${ }^{59}$

Unfortunately for Mariazell, however, Joseph II's reforms marked only the beginning of decades of disasters that threatened its very existence as a town, most of them completely outside even the most ambitious emperor's power to direct or prevent. During the French Revolutionary and Napoleonic wars, Mariazell was repeatedly threatened with invasion. Troops passed through frequently and were even quartered in town, at the cost, according to one survivor, of "wine, bread, flour, meat, leather, cheese, sugar, stockings, shirts, table linens, clothing, even my three pairs of boots." ${ }^{\prime 60}$ In the 1810 s and 1820 s, a series of fires laid waste to Mariazell, and the entire region suffered from famine. Mariazell's economic wellbeing depended upon a resuscitation of Marian pilgrimage and the exogenous traffic that it brought in tow-but to compete for pilgrims' attention in the nineteenth century would require more than rehashing centuries' old miracles: it would require transforming Mariazell

\footnotetext{
${ }^{57}$ Ibid., 185-86. “Österreich” was often used to refer locally to the province "Niederösterreich,” or Lower Austria. Waid, Mariazell, 125.

${ }^{58}$ The preface concludes with an admonition to pilgrims: "Liebe Marianische Wallfahrer! Ziehet in Gottes Namen aus und habet Acht, daß ihr auch ein gutes Zeugniß bei denen bewahret, welche, wie der Apostel sagt, draußen sind (1. Timoth. 3, 7), d.h. nicht unseres Glaubens sind, damit sie nicht Böses wider euch sagen können.” Nowohrácky, Jubiläums-Festblühten, 7-9. Nowohrácky's summons to the pilgrim whose duty (in addition to honoring Mary and being devout) was to defend the institution of pilgrimage with flawless, irreproachable behavior, was echoed half a century later in a prayer book advising, "one should always bear in mind that the pilgrimage path is a path of penitence, not a pleasure journey." Lieder-Kranz und Gebetbuch zum Gebrauche der Wallfahrer nach Maria-Zell, 7th ed. (Graz, 1903), 6.

${ }^{59}$ Josef Götten, Christoph Moufang, Theologe und Politiker, 1817-1890. Eine biographische Darstellung (Mainz, 1969), 98.

60"Mariazell im Jahre 1805," undated manuscript written in the first person, unlabeled carton [Mariazell], SAStL.
} 
into an attractive tourist destination. In the words of Pieter Judson, "tourism brought a real promise of a broader economic prosperity only to those rural communities flexible enough in their outlook to take good economic advantage of the opportunities it offered." ${ }^{61}$ How far could a pilgrimage site go without sacrificing its essential character?

Even after pilgrimage was reinstated (a gradual process that began in 1796) and St. Lambrecht's was restored (in 1802, although without most of its previous holdings), Mariazell faced an uphill battle. ${ }^{62}$ In 1797, the first pilgrimage season after Francis II/I restored the right of the Viennese to process to Mariazell, 131,000 pilgrims arrived, despite the ongoing war with France. ${ }^{63}$ Shortly thereafter, however, traffic dropped sharply. From 1814 to 1818 , Mariazell averaged 100,900 pilgrims a year, fewer than arrived in $1692 .{ }^{64}$ The ban on pilgrimage, the ravages of the marauding French troops, famines, a fire in 1827 that laid waste to the entire town, and a wave of cholera epidemics together made the transition from the eighteenth to the nineteenth century one marked by vulnerability and hardship. ${ }^{65}$ The glory days of pilgrimage to Mariazell seemed to be over (although not the glory days of Marian pilgrimage in general). At the same time, however, Central Europeans' interest in spending leisure time in the mountains and their conviction that mountain environments were healthy for body and soul both grew.

In his work on pilgrimage in the Nansa Valley in northern Spain, William Christian explains that shrines are unique because of their connection to a particular landscape. Often they are to be found at boundaries "between village and village" or "between cultivated and uncultivated land" or at "contact points with other worlds," such as "mountain peaks, springs, and caves." ${ }^{\prime 66}$ Mariazell's location was in many ways liminal: nearly equidistant from Vienna (the seat of central government) to the north, Graz (the provincial capital of Styria) to the south,

\footnotetext{
${ }^{61}$ Pieter Judson, Guardians of the Nation: Activists on the Language Frontiers of Imperial Austria (Cambridge, MA and London, 2006), 157.

${ }^{62}$ On St. Lambrecht's remaining properties, Waid writes, “was übrig blieb - die Pfarreralm mit etwas Wald, der Hausgarten, die kleine zusammengeschrumpfte Landwirtschaft - ist im Vergleich zum Verlorenen kaum nennenswert, wirklich nur ein kläglicher Rest." Waid, Mariazell, 133. It is interesting to note that it took the more conservative Francis II/I, who came to the throne in 1792, four years to begin the process of reintroducing pilgrimage and a full ten years to reinstate St. Lambrecht's. The emperor had to overcome, among other obstacles, resistance from the archbishop of Vienna and the majority of members of the Lower Austrian diet, who considered the pilgrimages to Mariazell to be an illegal exception to the general ban. The first pilgrims from Vienna to Mariazell were allowed to make the journey from 11 to 18 August 1796. Although initially only special pilgrimages from Vienna were allowed, pilgrimages from other towns were openly planned and even announced in newspapers, leading to general confusion about the validity of the ban. Hollerweger, Reform des Gottesdienstes, $342,345,372$. On the reintroduction of pilgrimage from Vienna to Mariazell in 1796: Rechenschafts-Bericht der Vereinsleitung des Wiener Mariazeller-Processions-Vereines für das Vereinsjahr 1896 (Vienna, 1897), 26. Adam Bunnell notes, "Francis, himself a pious man, was in no hurry to have the religious orders back, nor did he wish to restore their lands and riches, which had gone to support a growing bureaucracy and education and hospital systems." Bunnell, Before Infallibility, 43.

${ }^{63}$ Nowohrácky, Jubiläums-Festblühten, 129.

${ }^{64} 1814$ : 92,500; 1815: 86,100; 1816: 98,800; 1817: 110,300; 1818: 116,800. Sterz, Grundriß, 223.

${ }^{65}$ In the cholera year 1831, for example, only 154 processions were made to Mariazell. Prozessionen Protokol 18311844, unlabeled carton [Mariazell], SAStL. In 1834, Superior P. Christoph Stingl was reprimanded (and threatened with removal) by the monastery administration in St. Lambrecht for denying "the necessary spiritual assistance" to pilgrims out of a misplaced "frugality" - an indication either of Stingl's Josephinist leanings or continued hardship for the parish. Letter from Stifts Administration St. Lambrecht, ex offo, to P. Christoph Stingl, Superior zu Maria Zell, 2 April 1834, No. 72. Karton: Mariazell: Kirche. SAStL. The 1827 fire, which destroyed 75 out of 98 buildings, inspired fundraising efforts across the monarchy, including a benefit concert in distant Innsbruck. "Verzeichniss der Musik-Stücke,” Karton: Mariazell: Div. Bilder u. Kleinschriften, Gebetszettel, Fotos, Plakate, Flugzettel, SAStL.

${ }^{66}$ Christian, Person and God, 44, 181.
} 
and St. Lambrecht, its mother abbey, to the southwest; on a small hill in a valley, but encircled by mountains on all sides; near the point where the Alpine mountains dwindle into the Danubian plain; on the border between two provinces, Lower Austria and Styria. In all these ways, Mariazell was located at the juncture of two opposites: peak and valley, capital and province, secular authority and religious authority, mountain and plain. ${ }^{67}$

But geography is more than just location: the lure of nature can become an attraction all its own. In the nineteenth century, Mariazell began to draw visitors perhaps only ostensibly less devout than the idealized image of the pious pilgrim, a development that inspired either alarm or hope depending on the attitude of the observer. Tourism can threaten to replace devotion, but it can also supplement devotion. Pilgrimage scholars Mary Lee and Sidney Nolan have argued that the distinction between pilgrim and tourist is a difficult one to make in contemporary society, because "it is entirely possible for a visitor to come as a casual tourist and, because of emotions experienced at the shrine, return for another visit as a pilgrim." It is also possible that a pilgrim motivated principally by piety to visit a shrine may also enjoy the amenities and secular pleasures associated with the surrounding area. Nolan and Nolan suggested "religious tourist" as a neutral term, recognizing "a broader range of motivations for visiting places associated with religious history, art, and devotion."

One must be careful not to compare the nineteenth century tourist-pilgrim against an idealized type. Worrying about pilgrims traveling for the wrong reason (for example, to get away from work or to intermingle with pilgrims of the opposite sex away from the strictures of village society) was nothing new. Pilgrimage has long been recognized as having created "preexisting "cultures of travel" that complemented both tourism more broadly and "the culture of the "cure"." ${ }^{69}$ Nevertheless, concern that regard for the natural beauty of the region might distract from the centrality of Marian devotion in visitors' thoughts was a novel nineteenth-century concern. In his 1819 guidebook, Sterz notes, in the first published indication of nature tourism in the region, that "Maria-Zell is visited by many merely with the intention of procuring great pleasure from the view of the magnificent surroundings of this town."70 To the extent that Mariazell's natural surroundings were not only aesthetically pleasing, but also spiritually and even physically restorative, that pleasure, though, had its own utility. In 1823, before his conversion to Catholicism and ordination as a priest, the German poet Zacharias Werner described the procession from Vienna to Mariazell as a kind of spiritual cure: "the annual procession from Vienna covers the journey by foot, with less comfort than profit [Nutzen], in four and a half days. [The road to Mariazell] appears to be preferentially marked by nature as the way to a place of mercy, that is, to such a place as bestows upon an ailing soul that which an appropriate spa-cure bestows upon an ailing body -but is by far not so amusing to debauched souls as the distractions of the bath-season are to debauched bodies." 71

The appreciation of Alpine majesty noted by Sterz continued to grow over the course of the century. Clambering through the mountainous regions of Switzerland was already a popular

\footnotetext{
${ }^{67}$ Mariazell lies $118.9 \mathrm{~km}$ or 14 imperial miles from Graz and $139.1 \mathrm{~km}$ or 18 imperial miles from Vienna. At 862 meters above sea level, Mariazell lies between 295 and 300 Klafter above Vienna, but substantially below the peaks of the surrounding mountains, which reach heights of up to 2,227 m. Rögl, Maria-Zell, 222; Waid, Mariazell, 23, 24; Sterz, Grundriß, 182.

${ }^{68}$ Nolan and Nolan, Christian Pilgrimage, 43.

${ }^{69}$ Steward, "Tourism in Late Imperial Austria," 113.

${ }^{70}$ Sterz, Grundriß, 192-97, 223.

${ }^{71}$ Zacharias Werner, “Topographische Curiositäten," in Balsaminen, by E. J. Veith (Regensburg, 1837), 109-10 (first published in Vienna in 1823).
} 
secular enjoyment: "common enough," in the words of Simon Schama, "to suggest that it was indeed becoming a form of surrogate campaigning, akin to fencing or hunting." ${ }^{72}$ Recognizing this trend, guidebooks written in the second half of the nineteenth century used it to their advantage as they recommended Mariazell to the potential traveler. One guidebook included a listing of all 429 species of plant to be found in the mountains surrounding Mariazell for the benefit of the amateur naturalist. ${ }^{73}$ Another, issued in multiple editions over the course of the 1850s and 1860s, added to traditional sections on the foundation of the church, its history of fires, the contents of the treasury, and a register of indulgences granted to pilgrims, an entire section on "commendable excursions from Mariazell into the immediate vicinity." 74 Yet another appended a table of the trails in the region and their color-coded markings for the assistance of those suffering from Wanderlust during their visit, as well as distances to nearby sights and towns. ${ }^{75}$ Throughout the century, guidebooks to the Alpine pilgrimage site of Mariazell that were directed both at "pious pilgrims" and at "harmless friends of nature" proliferated-already by the 1830s, they were so common that the wise author had to preface his book with a justification of its existence. ${ }^{76}$

All of these guidebooks notwithstanding, despite sporadic increases in popularity over the next century (for example, the 700th anniversary celebration in 1857 , which saw the arrival of 270,000 pilgrims), Mariazell did not enjoy the surge in attention devoted to other Marian sites during the latter half of the nineteenth and first half of the twentieth centuries. ${ }^{77}$ It was still frequented by the ruling elite, still associated with the empire's glorious past, classified as an imperial holy treasure, and hailed as the spiritual possession of Germans, Slavs, and Magyars alike. ${ }^{78}$ Yet, although the railroad crossed the Semmering in 1854, direct rail access to Mariazell was not provided until 1907, more than fifty years later. More revealing still, although three million people visited French shrines in $1876(100,000$ of whom gathered in a single day to witness the consecration of a statue of the Virgin Mary at Lourdes) and two million gathered at Trier for a display of the Holy Coat in 1891, a mere 37,000 pilgrims visited Mariazell in the war year 1866 and only 48,000 in $1887 .^{79}$ In the half century

\footnotetext{
${ }^{72}$ Schama, Landscape and Memory, 495.

${ }^{73}$ Nowohrácky, Jubiläums-Festblühten, 65-70.

${ }^{74}$ Ursprung und geschichtliche Darstellung des weltberühmten Gnaden- und Wallfahrtsortes Maria-Zell (Maria-Zell, $[1857,1860,1868])$. Those recommended excursions included trips to lakes and waterfalls, both staples of romantic excursions into nature. The Erlauf-See and the Lassingfall were perhaps set apart by the large artificial lake (Stausee) created to ensure that the electric power plant at Wienerbruck could run for one month without any rainfall at all. Wilhelm Hartl, Illustrierter Führer auf der Niederösterr.-steirischen Alpenbahn Mariazeller Bahn (Vienna, 1926), 4.

${ }^{75}$ Rögl, Maria-Zell, 220-23.

${ }^{76}$ Mathias Macher, Der berühmte Wallfahrt-Ort Maria Zell in Steiermark historisch topographisch dargestellt nach seinem Wiederaufbaue aus den Brandruinen vom Jahre 1827 nebst einer treuen Schilderung seiner merkwürdigsten Umgebungen (Vienna, 1832), iii.

${ }^{77}$ Waid, Mariazell, 167.

${ }^{78}$ Although frequent visits from archdukes and archduchesses ensured that the Habsburg family would continue to be represented at Mariazell, Francis Joseph allowed over half a century to elapse before returning to Mariazell for a second visit in 1910. Even Joseph II had visited more often.

${ }^{79}$ Documenting the exact number of pilgrims is not possible. The most readily available proxy is the number of consecrated wafers, or hosts (Hostien) distributed. This number is available sporadically in the nineteenth century. From 1816 to $1819,2,341$ processions arrived with 1,159,000 pilgrims, for an average of 173 processions and 82,000 pilgrims per year. (Notation by Othmar Wonisch, Karteikatalog SAStL). Lourdes and Trier: Blackbourn, Marpingen, 38-40. Mariazell: Waid, Mariazell, 168. Some allowance must be made for the fact that Austria was at war (with Prussia) in the summer of 1866.
} 
following the 1857 jubilee, Mariazell averaged no more than 80,000 pilgrims annually, dropping to an average of 70,000 for the first decade of the twentieth century. ${ }^{80}$

Local townspeople responded by redoubling their efforts to ensure that tourism in the region continued to flourish. In 1877, a Touristenklub was founded, which was followed in 1880 by a "beautification club" with the declared purpose of "striving for the beautification of the markettown of Maria-Zell and its environs, and its formation into as pleasant a habitation as possible for locals and newcomers." ${ }^{\prime 1}$ Hotels, restaurants, souvenir shops, and multiple competing photography studios with panorama shows provided for the physical comfort and entertainment of visitors while they were not in church. ${ }^{82}$ Although no statistics on secular visits to Mariazell are available for the nineteenth century, one can measure their presence indirectly through the flourishing of local businesses. In the decades before the First World War, the Fotoatelier Kuss took an average of 300 carefully posed photographs a day of visitors set before painted backdrops of the church and the surrounding mountains. ${ }^{83}$

Church authorities were concerned that pilgrims would lose sight of the real reason for a visit to Mariazell. The appreciation of nature, they insisted, should not distract the pilgrim from pious reflection. At the same time, church authorities recognized that interest in mountain landscapes need not be entirely detrimental to pilgrimage; nature in its majesty could, if viewed correctly, strengthen the religious experience. Heinrich Nowohrácky's 1857 guidebook, published with the approval of the cathedral provost in Graz, noted: "When the pious pilgrim wishes to combine his journey of pilgrimage and repentance to the Virgin Mother in Maria Zell, undertaken in devotion, with a few interesting excursions in the lovely environment, his search for and observation of natural amenities should not fill him with profane thoughts, but rather bring him closer to the only goal and end of his earthly toil." Nowohrácky's guidebook not only tells pilgrims with a romantic sensibility where to go and when, but it also provides them with the history of ruins they pass, imaginative anecdotes about suicidal virgins betrothed to charmless old knights, and inspirational descriptions of the region's natural beauty.

In Nowohrácky's telling, Mariazell's mountainous location enhanced its sanctity: “So every blade of grass in the great temple of nature, in flowering copse and forest gloom, on mountaintop and alpine valley calls out to us an earnest word; yes, it even seems as if the holy scriptures had hidden a different text in each flower." Nowohrácky even presents Mariazell in its valley as an earthly metaphor for the Virgin Mary in heaven: "Just as Mary is

\footnotetext{
${ }^{80} \mathrm{Rögl}$ calculates an average of 80,000 pilgrims for the period 1857-1900, Rögl, Maria-Zell, 50. The average number of communicants recorded in Mariazell between 1839 to 1894 was 74,330 pilgrims a year. "Kommunikanten in Mariazell, 1839-1894," Karton: "Prozessionen," SAStL. Suzanne Kaufman estimates that Lourdes drew between 150 thousand and 300 thousand pilgrims annually in the early twentieth century, with the exception of the anniversary year 1908, in which one million pilgrims gathered for a jubilee celebration. Kaufman, Consuming Visions, 26, 212n15.

${ }^{81}$ Statuten des Verschönerungs-Vereins Maria-Zell, SAStL, Nachläße (NL).

${ }^{82}$ Laurence Cole has noted that Tirol was "an innovative region in the tourist branch" that smoothly transitioned from a world in which "the lodging of travelers and hospitality were once linked to a religious conception of the fulfillment of duty and neighborly love" to one in which "tourism was a business that was intimately connected with capitalist society." Laurence Cole, "Für Gott, Kaiser und Vaterland": Nationale Identität der deutschsprachigen Bevölkerung Tirols 1860-1914 (Frankfurt, 2000), 381.

${ }^{83}$ Several of these photographs are reproduced in Andreas Schweighofer, Thomas Schweighofer, Ernst Leitner, and Josef Grießl, eds., Ranti Putanti, s' Leben is hanti: Mariazeller Erinnerungen, Bilder aus vergangenen Tagen, vol. 1, 1864 bis 1938 (Mariazell, 2002). The population of Mariazell rose from 1,151 residents in 134 houses in 1869 to 1,984 residents in 188 houses in 1910 (in 1981 the town had only 1,926 residents). Blumauer-Montenave, "Tabelle 1: Häuser und Einwohner 1390 bis 1981," in Zur Geschichte des Wallfahrtsortes Mariazell, 27.
} 
the eternal highlight of divine power and heavenly beauty in the choir of blessed spirits, so is Maria-Zell in the middle of its fragrant mountains the most magnificent highlight of romantic alpine spots out of whose circle we point out those most worthy of a visit." The title of his guidebook's seventh chapter transformed the Alps' inspirational pleasures into the celebratory devotion of church attendance: "Alpine joy and devotional service: A pilgrimage donation upon leaving the temple of nature and entering the temple of Mary." ${ }^{84}$ Imbuing nature with sacred symbolism combined nature worship and Christian worship.

Even children observing Slovak- and Hungarian-speaking pilgrims arriving from the Hungarian steppe knew that they had come for Mary, not for the mountains-their awe inspired by the church, not the Hohe Veitsch behind it. In his childhood memoir, Heimatauthor Peter Rosegger asks, "Did the people from the plains greet the wildly sublime alpine nature? No. Their holy destination lay in the rocky crown of those mountains." ${ }^{85}$ It is not Mariazell's location that made it what it was, argued one local entrepreneur in 1907: "the natural beauty of this region ... doubtless constitutes an attraction in and of itself, but alone would by no means suffice to direct such a stream of travelers to Maria-Zell. For nature is also beautiful elsewhere. But here, it is the setting for a sanctuary of the Catholic world ... it would be condemned to a shadow-existence in the very moment when the Marian cult ceased to exist." 86

Acceptance of the duality of religious Alpine tourism was matched by an uncertain evaluation of modern technology and modern tourism's effects on Mariazell, manifested in the juxtaposition between the local mountain folk and the pilgrims, often from distant cities and villages. Outsiders simultaneously admired the quaint and spiritually noble rusticity of the locals and bemoaned their backwardness. Mariazell's landscape was admired for its unspoiled beauty even while its connection to the outside world was celebrated by guidebooks written to extol the new railroad after its construction reached the town in $1907 .{ }^{87}$ The juxtaposed celebration of technology and tourism, on the one hand, and heralding of traditional peasantry and the Arcadian landscape of rural Austria, on the other hand, was not, of course, limited to Mariazell. On the contrary, it was the central characteristic of a Christian Social Party that borrowed its celebration of the peasants from agricultural conservatism even while standing, in the words of Gavin Lewis, "squarely on the side of the economic, cultural, and political [transformation] of rural life," thanks to investment in the construction of schools, the expansion of railroads, and the foundation of rural cooperatives. ${ }^{88}$

Nevertheless, the difference between mountain folk and city folk was a popular theme for nineteenth-century writers. Something about the mountain residents' nature was perceived to

\footnotetext{
${ }^{84}$ Nowohrácky, Jubiläums-Festblühten, 64, 77, 101.

${ }^{85}$ Peter Rosegger, Als ich noch der Waldbauernbub war: Geschichten aus der Heimat, paperback edition (Munich, 1996), 99. Originally published in three volumes, 1899-1902.

${ }^{86}$ Rögl, Maria-Zell, 71.

${ }^{87}$ The forward to Rögl's 1907 account ends: "Möge das Buch im Interesse von Maria-Zell und zum Vorteile der neuen Bahn von Erfolg begleitet sein.” Rögl, Maria-Zell, viii. It was also in 1907 that Pius X elevated the church in Mariazell to the status of a basilica, granted a plenary indulgence to pilgrims to Mariazell and also issued the encyclical "Pascendi Dominici Gregis," the "high point of his battle against the teachings of modernism." Friedrich Engel-Janosi, Österreich und der Vatikan, 1846-1918, vol. 2, Die Pontifikate Pius' X. und Benedikts XV (1903-1918) (Graz, 1960), 88; "Dekret der Erhebung der Kirche in Mariazell zu einer Basilika" 27 November 1907, Karton: "Diverse Archivalien," SAStL.

${ }^{88}$ Gavin Lewis, "The Peasantry, Rural Change and Conservative Agrarianism: Lower Austria at the Turn of the Century," Past and Present 81 (November 1978): 128.
} 
span time and state boundaries-and this unique type was increasingly viewed as a model for all. "Our Alps," wrote the Archduke Johann of Austria, "have what I need, they have an unspoiled people.... The belt that holds these peoples stretches from the Jura to the Neusiedler Lake-it is, in my mind, the best in our exhausted, antiquated, spoiled part of the world." ${ }^{89}$ Mariazell's residents, like the residents of the surrounding region, were perceived to be shaped by the landscape in which they lived-like the mountains, they were rugged and strong. According to Sterz, "The beautiful, healthy race that one finds here and the rarity of illnesses, are the greatest proof of the good location." ${ }^{\prime \prime 0}$ In 1819, such paeans of praise for the virtue of mountain people were just beginning to overtake the previously dominant currents condemning their stupidity, or noting the high incidence of cretinism, goiter, alcoholism, and violence. ${ }^{91}$ Was it the fresh mountain air that accounted for their newly lauded purity of heart and strength of constitution? Or the proximity of Mariazell? Archduke Johann, who often visited Mariazell, wrote in his journal on 30 April 1818: "I never enter this house of God without emotion.... The Styrians kneeling here, wandering around the chapel, the childlike faith emanating from all of them-could that fail to be moving?"92 By midcentury, the celebration of the local population's simplicity, virtue, and rugged good health was so prevalent as to seem clichéd.

A defense of the virtues of mountain folk could quickly turn into a tirade against the alleged superiority of the progressive, liberal element in society, as it did in Nowohrácky's 1857 guidebook: "It is the uncharitable habit of many townspeople, while they imagine themselves to be at the glittering level of enlightened cultivation, to want to deny any spiritual improvement, any human civilization and immediate education to the simple country folk, and even more to the highlanders living between lonely mountains." He then reassured his readers that "here in the mountains, there may be less vain egocentricity, but in exchange more common sense and open-hearted sincerity." This last quotation is followed by the story of a boy in Germany who attempted suicide out of sheer boredom. Mariazell's local boys, the author claims, are surely not "clever" enough to cook up such a scheme as that. Living in the mountains, their characters mirrored their natural surroundings: "Like the clear mountain spring, the mind of youth is pure and innocent." 93 Even the air was imbued with special characteristics. When the Jesuit priest Heinrich Abel initiated the annual Wiener Männerfahrten to Mariazell in 1893, he was motivated not only by his concern that pilgrimage had become unduly feminized and that the spiritual care of Viennese men was

\footnotetext{
${ }^{89}$ Archduke Johann of Austria, Der Brandhofer und seine Hausfrau, 3rd. ed., rev., with an introduction by Walter Koschatzky (Graz, 1982), 64. Johann completed the autobiographical story by 1850 , but it was not published until 1930, 71 years after his death.

${ }^{90}$ Sterz, Grundriß, 189.

${ }^{91}$ Deborah Coen has connected the phenomenon of the Sommerfrische-which drew "Austria's liberal Bildungsbürgertum" from the city (Vienna) for a sojourn in the countryside to a new "admiration for the "inner nobility' of the alpine peasants." She cites a poem by Hugo von Hofmannsthal in which he extols "Who do not watch for the mysterious / Blue beauty of this water / Nor its fragrance and grace / But for the meager / Growth of their scrawny crops / For the fruit of the small garden / For food to live on." Deborah Coen, Vienna in the Age of Uncertainty: Science, Liberalism, and Private Life (Chicago, 2007), 19. For a discussion of stereotyping of mountain peoples in southeastern Europe, see Karl Kaser, "Peoples of the Mountains, Peoples of the Plains: Space and Ethnographic Representation," in Creating the Other: Ethnic Conflict and Nationalism in Habsburg Central Europe, ed. Nancy Wingfield (New York, 2003), 216-30.

${ }^{92}$ Andreas Posch, "Erzherzog Johanns kirchlich-religiöse Einstellung," in Erzherzog Johann und die Steiermark: Elf Vorträge zum Steierischen Gedenkjahr, ed. Ferdinand Tremel (Graz, 1959), 26. Johann first visited Mariazell in 1796 at the age of 14 .

${ }^{93}$ Nowohrácky, Jubiläums-Festblühten, 61, 99.
} 
deficient, but also by his concern for Viennese men's physical well-being. To the question "Why Mariazell?" he answered, "First of all, the Viennese have grown fond of Mariazell. Secondly, it is a truly pan-Austrian pilgrimage site. Thirdly, I tell you candidly that I want to grant my dear Viennese men some free movement in fresh mountain air after their labor in dark workshops and narrow streets." 94

The interaction among pilgrims, tourists, and locals should, then, have been mutually beneficial-but on whose terms? From the very first, outsiders came to Mariazell with a civilizing mission. When Mariazell was first established by St. Lambrecht's, it was not because the monks wanted to learn from the "noble savages" who lived there. On the contrary, they sought to transform the local population by bringing "civilization and religion where it was needed" and in exchange to win control over substantial salt and iron ore deposits for the mother abbey. ${ }^{95}$ By the early twentieth century, however, it seemed to some local entrepreneurs that outsiders brought not civilization, but bad habits. Hans Rögl, the owner of a photography studio in Mariazell worried that "the interaction with the many visitors that come here every year cannot remain without influence."96

The condemnation of outside influence was laced with overt anti-Semitism. A 1907 newspaper article praised the "high mountain air" for being "rassenrein" and complained that someone should clear "Jewish newspapers" from the local inns. ${ }^{97}$ A series of articles published in the Catholic daily, Die Reichspost, in 1914 asserted that even the "production and trade of pilgrimage goods, christening and confirmation presents, etc." was in the hand of Jews, warning, "one thing is certain: everywhere where recreation sites, spa-baths, sports fields are founded, Jews tend to appear first, in order to do business there regardless of whether they are welcome or uninvited guests." 98 Although it was not only Jews who were labeled as outsiders, it seemed possible to live peaceably with other secular visitors. Othmar Wonisch, subprior and archivist of St. Lambrecht's (and Mariazell's most prolific historian), noted in the margin of a 1907 newspaper clipping, "The tourists have their alpine climbs, we 'plain folk' [gemoana Leut] our pilgrimages. If they're satisfied with it, so

\footnotetext{
${ }^{94}$ P. Abel S. J. und die Wiener Männerfahrten nach Mariazell (Vienna, 1907), 15, as cited in Othmar Wonisch, ed., Mariazell 4, no. 7 (1917): 157.

${ }^{95}$ Rögl, Maria-Zell, 17. Of course, they also wished to stake a claim to local natural resources: "Salz und Eisen aus dem Mariazeller Bereich waren für das Mutterkloster Ansporn, die Erschließung dieses entlegenen Siedlungsraumes voranzutreiben." P. Benedikt Plank, OSB, "St. Lambrecht und Mariazell," in Helmut Eberhart and Heidelinde Fell, eds., Schatz und Schicksal: Steirische Landesausstellung 1996. Mariazell and Neuberg an der Mürz, 4. Mai bis 27 Oktober (Graz, 1996), 15.

${ }^{96}$ Rögl, Maria-Zell, 152. By the 1850s, Archduke Johann, the Habsburgs' staunchest Alpinist, looked back with nostalgia on the days before city influence made itself felt in the region: "Es herrschte alte Treue, alte Sitte, Wohlhabenheit, und wie überall, wo Eintracht, Rechtschaffenheit und Einfachheit herrschen, ächter Frohsinn ... noch waren nicht fremde Sitte, nicht städtisches Wesen, nicht Luxus, nicht das Verderbniß über die Pötschen herübergewandert, denn jenseits hatte sich noch nicht das bunte Treiben der Hauptstadt eingebürgert.” Archduke Johann, Der Brandhofer, 60.

97 “Eine Blitzwallfahrt nach Maria Zell” (Lambach, 17 May 1907), newspaper clippings (the title of the newspaper is unfortunately not included), with marginalia in Othmar Wonisch's hand. SAStL, unlabeled carton.

${ }^{98}$ The article went on to complain: "Viel beklagenswerter und trauriger aber ist noch, daß heute noch unter den Augen der christlichen Geschäftswelt der Großteil der Erzeugung und Handel von Wallfahrtswaren, Christ- und Firmungsgeschenke usw. die Juden in Händen haben und mit diesen Artikeln die besten Geschäfte machen." "Die Verjudung von Mariazell," Reichspost no. 31 (20 January 1914). For an argument that "seaside and spatown antiSemitism" developed independently from anti-Semitic political parties both because it was "deeply anchored in [German] society" and tied to "sociocultural developments that were tightly bound to the social function of the journey to a spa before the emergence of modern mass tourism," see Frank Bajohr, "Unser Hotel ist judenfrei": Bäder-Antisemitismus im 19. und 20. Jahrhundert (Frankfurt, 2003), 21-37.
} 
are we." 99 To condemn all interaction with outsiders would be suicidal for a town whose livelihood depended on pilgrimage.

Just as friends and defenders of the church bemoaned the godlessness of modern liberalism, they celebrated Mariazell's entry into the new twentieth century. The same town that appealed to visitors to appreciate its rustic beauty began to brag of modern convenience and technology. Telling in this regard are the advertisements included in Hans Rögl's 1907 guidebook. An advertisement for a panoramic show in the newly constructed "photography building" in the main square (boasting presentations of the origin of Mariazell, panoramic views, and a passion play) combined religious, historical, and nature-tourist content with a modern, technologically advanced format. ${ }^{100}$ An advertisement for the latest in travel and sports equipment and costumes is flanked on one side by an advertisement for religious articles carved out of wood and on the other side by one for Styrian silver fir tree perfume. This perfume, in an interesting twist on the "holy water" to be found at sacred sites, was "guaranteed [due to its ozone content] to bring the fresh, healthy mountain air into your home." Religion, natural bounty, and tourism flourished side by side, as did the latest advances in Alpine outfitting and the oldest, "most traditional" recipes for Mariazell stomach drops.

Perhaps most indicative of the change in the experience of visiting Mariazell was the gradual encroachment of the railroad. That travel to Mariazell in the absence of the railroad had been physically challenging is suggested not only by contemporary guidebooks and extant schedules of actual pilgrimages, but also by the fact that the small town of Mariazell, with only 800 residents, could support six cobblers. ${ }^{101}$ Shoemakers were the single largest group among the town's sixty artisans, for the simple reason that pilgrims frequently arrived with shoes in a state of terrible disrepair. Only in the 1860s did it become possible to travel through the Mariazeller region comfortably by carriage. ${ }^{102}$

The transformation of pilgrimage from a weeklong roundtrip journey by foot to a day trip made by train was not immediate, but proceeded in several stages. In 1878, the Wiener Maria-Zeller-Prozessions-Verein, which had been organizing pedestrian pilgrimages from Vienna to Mariazell since the late eighteenth century, started to take the train for the stretch from St. Pölten to Lilienfeld, which reduced the trip from nine to five days and lowered its cost. ${ }^{103}$ Even after the railroad was extended to Kerndorf, a five-hour foot march separated

\footnotetext{
99“Die Touristen haben ihre Hochtouren, wir 'gmoana Leut' unsere Wallfahrten. Sind sie es zufrieden, wir auch.” “Eine Blitzwallfahrt nach Maria Zell” (17 May 1907), unlabeled newspaper clipping, Karton: Nachläße, SAStL.

${ }^{100}$ A similar advertisement appeared in Entstehung von Mariazell nebst kurzer Beschreibung der Gnaden-Basilika (Mariazell, [1914-1920]): "Sehenswert! Panorama in Mariazell. Erste Abteilung. Ursprung und Entwicklung des Gnadenortes vom Jahre 1157 bis auf heute, in prachtvollen Lichtbildern. Zweite Abteilung. Kinematographische Vorführungen religiösen Inhaltes. Wechselndes Programm. Im selben Gebäude befindet sich auch das photographische Atelier J. Kuß.”

${ }^{101}$ Sterz, Grundriß, 185. In 1907, the town's population had increased from 820 residents in 98 houses to 1,180 residents in 124 houses. Karl Reiterer, Illustrierter Führer durch Steiermark (Aussee, 1907), 20. Georg Göth was commissioned by Archduke Johann of Austria to survey the population and natural resources of Styria. His report (Bezirks-Summarium) on Mariazell claims it had 844 residents, of whom 468 were female. "Bezirks-Summarium vom Jahre 1837." Steiermärkisches Landesarchiv, Göth Georg Nachlaß, K. 34 H. 697. Multiple pilgrimage schedules can be found in SAStL, Karton: "Mariazell: Div. Bilder u. Kleinschriften, Gebetszettel, Fotos, Plakate, Flugzettel."

102“Reisegelegenheit in Obersteiermark," Mittheilungen des Österreichischen Alpen-Vereines (Vienna, 1864), 465.

${ }^{103}$ Der fromme Pilger nach dem Gnadenorte Maria-Zell in Steiermark. Ein Gebets- und Wallfahrtsbuch (Vienna, 1908), 17. According to the Verein's annual statements of accounts, an average of between 1,000 and 1,300 pilgrims took part in its annual pilgrimage to Mariazell. Rechenschafts-Bericht der Vereinsleitung des Wiener
} 
passengers from Mariazell. Only in 1907 was Mariazell connected directly to St. Pölten by rail-through 19 tunnels, over 155 bridges, and with an increase in altitude of 622 meters or 2,040 feet. ${ }^{104}$ Now pilgrims from Vienna could travel to the holy site and back in less than two days. ${ }^{105}$ This presented both an opportunity and a renewed challenge. On the one hand, Mariazell was more accessible and more attractive to those who only had enough time for a so-called "Blitz-pilgrimage," like the one from Lambach (near Linz, in Upper Austria) that brought its participants home "well-rested, which is not possible after a four or five day long peregrination." As the Kremser Zeitung noted in an article praising the comforts of the new railroad line, "what you spend on the express train you save on time, room, and board."106 On the other hand, what exactly did a pilgrimage mean in the absence of a strenuous journey? As Othmar Wonisch noted after the automobile had replaced the railroad: "Without any physical exertion, a trip, particularly in a softly upholstered luxury car with a built-in radio, cannot be a real pilgrimage."

Rögl predicted the railroad would become a beloved part of the local landscape-a monument to modernity. ${ }^{108} \mathrm{New}$ traffic patterns did influence the way in which people visited Mariazell by enabling them to reach certain spots more easily and by steering them away from others. In Wonisch's article on Mariazell's origin legend, for example, he notes the changing fate of the boulder believed by the faithful to be the same one that blocked the founding monk's path as he set out into the mountains. "This rock used to be popular with pilgrims, but today [1949], a sign of modern traffic, the spot is falling ever more into oblivion, the more so as the area is already spoiled by construction."109 The emperor's travel plans were also adapted to the new railroad routes. When Francis Joseph visited Mariazell in 1910 (after a 53-year hiatus), he arrived by a train that paused twice to allow the imperial guest to soak in the romantic panorama. ${ }^{110}$ During his visit, the emperor asked about the further development of construction of the railroad, pilgrimage and its organization, and winter sports, particularly skiing. ${ }^{11}$ Technology and secular tourism had taken their place alongside religious pilgrimage.

Mariazeller-Processions-Vereines für das Vereinsjahr 1896 (Vienna, 1897), .. für das Vereinsjahr 1899 (Vienna, 1900), ... für das Vereinsjahr 1900 (Vienna, 1901).

${ }^{104}$ The difference in altitude between the railroad station in St. Pölten and that in Mariazell is 575.8 meters. The highest point reached by the railroad between those two stations is at the Gösingtunnel. Hartl, Illustrierter Führer, 3 , 58. Once the railroad opened in the spring of 1907, it became possible to travel from Vienna to Mariazell and back in one day, with a three- to four-hour stay in the pilgrimage town itself. Mitteilungen des deutschen und österreichischen Alpenvereins 8 (30 April 1907), 101.

${ }^{105}$ The schedule for a pilgrimage from St. Pölten to Mariazell shows pilgrims meeting at the local cathedral at 9:00 a.m., leaving for the train station at 10:00 a.m., and arriving Mariazell at 4:00 in the afternoon. They returned to St. Pölten at 4:30 the following afternoon, for a total commitment of 33.5 hours. "Wallfahrtsordnung," Karton: "Mariazell: Div. Bilder u. Kleinschriften, Gebetszettel, Fotos, Plakate, Flugzettel," SAStL.

106“Eine Blitzwallfahrt nach Maria Zell," Lambach, 17 May 1907, newspaper clipping, Karton: Nachlässe, SAStL.

${ }^{107}$ Othmar Wonisch, "Das Marianische Land,” unpublished typescript, Karton: Nachlässe, SAStL.

${ }_{108}$ "Sie [those who constructed the railroad] haben sich mit diesem hervorragenden Werke moderner Technik ein bleibendes Denkmal geschaffen." Rögl, Maria-Zell, 189. The section on daily excursions offers a list of "prächtige Ausflüge mit der Bahn.” Rögl, Maria-Zell, 213.

${ }^{109}$ Wonisch, "Mariazeller Ursprungslegende," 172.

${ }^{110}$ Francis Joseph's visit to Mariazell was motivated not only by the holy sanctuary and the railway, but also by a statue of the emperor erected by the naturalized Austrian industrialist, Arthur Krupp, who had invited the emperor to attend its dedication. Waid, Mariazell, 172-73.

${ }^{111}$ Nearly one hundred years later, nature enthusiasts Nicholas and Nina Shoumatoff admired the "Lourdes-type shrine of Mariazell, on whose surrounding slopes 'everyone in Vienna' is supposed to have learned to ski." Nicholas and Nina Shoumatoff, The Alps: Europe's Mountain Heart (Ann Arbor, MI, 2001), 31. 
With so much fostering of tourism and such an increase in the ease of travel, why, then, did Mariazell fail to flourish in the Gründerjahre of Marian pilgrimage? Victor and Edith Turner have argued that pilgrimage sites render traditional boundaries meaningless, or at least change their meaning: "The pilgrim trails cut across the boundaries of provinces, realms, and even empires." ${ }^{112}$ Nevertheless, they argue, Catholic pilgrimage can also be claimed as the property of an exclusionary group: "The danger is, of course, that Mary, in principle representing global communitas, has in practice become, in each of her numerous images, exclusive patroness of a given community, city, or nation. Wherever she has become such a symbol of xenophobic localism, political structure has subverted communitas." 113 William Christian documents a decline in local shrine popularity as nationalist sentiment became strengthened in the modern era, leading to an ever-greater attraction to national shrines. ${ }^{114}$ Nolan and Nolan use a shrine's range of drawing power as an indicator of its importance, measured both by the number of annual visits and the size of the geographical area from which the shrine draws religiously oriented visitors. Presumably national shrines draw pilgrims from a larger area; the "national designation is politically charged because these shrines are important religious symbols of nationhood." ${ }^{115}$ All of these factors indicate a sense of belonging associated with a particular shrine and a particular group of people-from the most universal (all Catholics) to the most exclusive (residents of a particular village). Residents of internationally recognized sites such as Lourdes had to share their site with all French men and women and beyond that with all Catholics. In return, they enjoyed the admiration, approval, and attention of millions of pilgrims each year, in addition to considerable material benefits from the pilgrimage trade. Did Mariazell suffer from the obvious irrelevance of national character?

Mariazell, though located in a homogeneously German-speaking region of the Austrian Empire, was never praised as the spiritual center of German-speaking Catholics. Rather, Mariazell was the shared property of all of the empire's Catholics: its Ehrentitel was "Magna Mater Austriae, Magna Domina Hungarorum, Magna Mater Gentium Slavorum." 116 Nor was Mariazell ever viewed as an exclusively Styrian pilgrimage. On the contrary, even its earliest history was marked by popularity throughout Central Europe; its first patrons came from Bohemia and Hungary. ${ }^{117}$ Mariazell was the goal of pilgrims "from all estates and nations"118 from all over the Habsburg monarchy, a metaphor for the polyglot empire itself. A parish priest asserted in 1913, "Just as the various nations contributed to the foundation of this venerable pilgrimage site, so is it still visited by all of Austria's nations. One can hear the different languages in this basilica, here every national conflict ends." ${ }^{119}$ The patron saints guarding the church's doors were chosen with an eye toward fair distribution-Wenceslaus (Wenzel, Václav) and Leopold to the north for the Bohemians and the Viennese, Ladislaus

\footnotetext{
${ }^{112}$ Turner and Turner, Image and Pilgrimage, 6.

${ }^{113}$ Ibid., 171.

${ }^{114}$ Christian, Person and God, 49.

${ }^{115}$ Nolan and Nolan, Christian Pilgrimage, 22.

116“"The Great Mother of Austria, Great Protectress of the Hungarians, and the Mother of the Slavic Peoples." Bowman, "The State, Popular Religion, and Political Power."

${ }^{117}$ One recent study of pilgrimage in Austria contains descriptions of well over 100 pilgrimage sites, organized by province (Bundesland). The only pilgrimage site not listed under one of Austria's nine provinces is Mariazell, which, instead of being classified under Styria, has its own section, entitled "Die Via Sacra." Pia Maria Plechl, Wallfahrt in Österreich (Vienna, 1988).

${ }^{118}$ Nowohrácky, Jubiläums-Festblühten, 3.

${ }^{119}$ Franz Stadler, "Maria-Zell," Kremser Zeitung 46 (15 November 1913).
} 
(László, Ladislav) to the east for the Hungarians, Aegidius (Aegyd, Giles) to the south for the Styrians-"so all the peoples and nations take great comfort and joy in the very sight of their familiar patrons." ${ }^{20}$ A list of more than 120 cities and regions making ceremonial processions into Mariazell in 1811 is organized into five groups, the archduchy of (Lower) Austria (including, at that time, Vienna), the Kingdom of Bohemia, the Kingdom of Hungary, the Duchy of Styria, and the Margravate of Moravia. ${ }^{121}$ It is telling that these are geographic, and not putatively ethnic, designations-they reflect the breadth of Mariazell's "catchment basin" without forcing its division into impermeable national categories.

Where it existed, a sense of national belonging or regional distinction did not conflict with a desire to visit an explicitly and proudly supranational pilgrimage site. Some pilgrims to Mariazell celebrated their self-perceived national heritage through costume and song even as, in the words of Victor and Edith Turner, their "likeness of lot and intention [was] converted into commonness of feeling, into 'communitas'," with members of other linguistic groups they found in Mariazell. ${ }^{122}$ The popular Styrian writer Peter Rosegger remembered watching streams of "foreigners," including bands of Gypsies, and even "a black" pass on the same path the "wild Turks" had once followed from "far-away Hungary-land" to Mariazell. But most impressive to the young Rosegger were the swarms of "Hungarians" and "Slavs" who made their way along the path during May to celebrate Ascension Day: "Hungarian lords and Slavic princes contributed a great deal to the fame and glorification of the holy site at Zell, and still today," wrote Rosegger, "the stream of those peoples flows toward the appointed Alpine valley and constitutes the greater part of the pilgrims that come to Zell every year." ${ }^{23}$ Mariazell's ability to draw pilgrims from far and wide, and its responsibility for them-the necessity for priests who could hear confessions and deliver sermons not only in German, but also in Czech, Slovak, Slovene, and Hungarian-was a matter of some local pride. $^{124}$

But by 1907, contemporary observers thought they had noticed a disturbing trend. Despite the jubilee celebrations, the emperor did not visit Mariazell that year, although the mayor of Vienna, Dr. Karl Lueger, did. Perhaps of greater concern than the emperor's absence, Rögl was convinced that Hungarian and Slavic pilgrims were fewer in number. "The national question, which in our times penetrates almost everywhere, also plays a role in the development of Mariazell. It is a fact that processions from Bohemia, Moravia, and Hungary come less often-some stay away altogether." He found Czech speakers' claims that they stayed away "because they were treated rudely on the journey and even in the place of mercy itself" implausible. How could Mariazellers be so shortsighted? "For even good common sense is enough to know that the absence of processions means economic disadvantage." Of more concern than the economic damage, however, was the precedent it established, turning the whole principle of Mariazell on its head. "Mariazell," Rögl argued, "is a place that cancels every difference in nationality with the strength of Catholic belief, and offers common

\footnotetext{
${ }^{120}$ Nowohrácky, Jubiläums-Festblühten, 56.

${ }^{121}$ Sterz, Grundriß, 220-21.

${ }^{122}$ On Slovaks: Rögl, Maria-Zell, 135. Quotation: Turner \& Turner, Image and Pilgrimage, 13.

${ }^{123}$ Rosegger, Als ich noch der Waldbauernbub war, 97, 98-99. Rosegger's childhood impression is confirmed by contemporary reports that, in the 1857 jubilee year, 27,000 pilgrims arrived from Hungary on 8 September alone9,000 of them from Preßburg/Bratislava-Prešporok/Pozsony (Coreth, Pietas Austriaca, 68). Rosegger, though celebrating the simple piety of his childhood, was considered to be critical of the Catholic Church, in particular after he donated funds for the construction of a Protestant church in Mürzzuschlag. Karlheinz Rossbacher, Heimatkunstbewegung und Heimatroman. Zu einer Literatursoziologie der Jahrhundertwende (Stuttgart, 1975$), 86$.

${ }^{124}$ Rögl, Maria-Zell, 132.
} 
foundation for the Catholic citizens of this state. Should this change? ... In a Catholic pilgrimage site, but especially one on Austrian soil, there can be no room for national thoughts." 125

In the empire's last decades, the only new and growing pilgrimage to Mariazell was the Wiener Männerprozession, or Wiener Männer-Wallfahrt, established in 1893 by P. Heinrich Abel SJ, under the motto "Back to practical Christianity!" Every year from 1893 until 1937, this procession gathered up to six thousand men from Viennese trade, academia, industry, and politics, along with farmers, students, and artisans. ${ }^{126}$ One of its most faithful participants was the mayor of Vienna, Karl Lueger. But Karl Lueger's Christian Social Party, though anti-Semitic and chauvinist, did not aspire to transform Austria into a homogeneously German-speaking nation-state. On the contrary, in sharp contrast to Georg von Schönerer's fringe Pan-German party, the Christian Socials were pro-German within the Viennese context, but pro-Habsburg, that is, pro-linguistic diversity, in the national context. According to John Boyer, their "use of religion was ... politically pluralistic and ... culturally utilitarian," and even within Vienna, "their way of thinking was as much corporate as it was 'national."'127

That Catholicism and nationalist chauvinism were incompatible and that driving tourists away would hurt Mariazellers' pocketbooks do not themselves prove that nationalist conflict did not diminish the appeal of a pilgrimage site in a German-speaking region to Slavic- or Hungarian-speaking Catholics. ${ }^{128}$ It is, however, possible to reconstruct statistics that can shed light on the alleged change in the geographic distribution of pilgrims to Mariazell. Tables maintained by the church and submitted to the mother abbey in St. Lambrecht list pilgrimage processions individually and record both the number of participants and either their hometown or their purported nationality. Although these tables are only available sporadically, and their reliability cannot be verified, they are suggestive. A comparison of pilgrims traveling to Mariazell in 1863 and in 1914 shows that the percentage of Slavicspeakers held steady at 27-28 percent and the percentage of Hungarian-speakers increased from 8 to 16 percent. ${ }^{129}$ Rögl's perception notwithstanding, responsibility for the decline

\footnotetext{
${ }^{125}$ Ibid., 146.

${ }^{126}$ Waid, Mariazell, 170. Leisching identifies Abel's organization as part of a group of religious clubs and events that demonstrated a "tactical demonstration of the expansion of anti-liberal and anti-socialist power." Leisching, "Die Römisch-Katholische Kirche,” 194.

${ }^{127}$ John Boyer, Culture and Political Crisis in Vienna: Christian Socialism in Power, 1897-1918 (Chicago, 1995), 166, 215.

${ }^{128}$ Indeed, the increasing popularity of Marian pilgrimage and the growth in the number of Marian pilgrimage sites itself created new competition for Mariazell in the nineteenth century. Popular pilgrimage sites in Cisleithania would include the following: in Moravia: Velehrad, Berg Hostein/Hostýn, Turas/Tuřany, St. Thomas in Alt-Brünn, Slaup/ Sloup, Wranau/Vranov, Sitzgraz/Cizkrajov, Žaroschitz/Žarošice, Običtau/Obyčtov, and Přibyslawitz/ Přibyslawice; in Bohemia: Přibram/Př́ibram. Albendorf/Vambeřice/Wambierzyce, Maria Kulm/Chlum Svaté Maří/Chlum nad Ohří, Altbunzlau/Stará Boleslav, Hrádek, Maria Sorg, Maria Stock/Skoky, Tuřan/Tuřany, and Makow/Makov; in Styria, Carinthia, Carniola, Gorizia, and Istria: Maria Luschari/Svéti Višarje/Monte di San Lussari, Bresiach/Brezje, Groß Kahlenberg/Šmarna gora, Maria Saal, Maria Grün, and Maria Schnee; in Vienna and Lower Austria: Klosterneuburg, Maria Stiegen, Maria von Pötsch, Maria Treu, Maria Taferl; in Upper Austria, Salzburg, Tirol, and Vorarlberg: Maria Eich, Maria Plain, Trens, and Rankweil; in Galicia: Podkamień/Pidkamiń, Kochawina/ Kochavyna, and Milatyn; in Lemberg/Lwów/L’viv: Kalwarya Pacławska, and Leżajsk. Among the most significant pilgrimage sites in Central Europe was the Black Madonna of Częstochowa in Upper Silesia. Leisching, "Die Römisch-Katholische Kirche," 135-36.

129"Die Processionen welche im Jahre 1914 in der Zeit vom 1. Mai bis 1. Juni in der Basilika kirchlich eingezogen sind," and "Processionen [sic] 1863, 1ten Concurs," Karton: "Prozessionen," SAStL. Calculations are based only on the month of May, in order to rule out any effect of the tensions associated with World War I. I grouped together processions listed as "slov.," "böhm. slov.," “mähr. slov.," “ung. slov.," and “croat." as "Slavic-speaking," and
} 
cannot be associated with any particular national category: the total number of pilgrims dropped sharply across all geographic and linguistic groups. ${ }^{130}$ If we eliminate nationalist conflict, what other possible explanations remain for the apparent decline in pilgrimage to Mariazell?

Those who find it anything but surprising that pilgrimage becomes less significant in an age characterized by anticlericalism and secularization will find it hard to account for the stunning popularity of pilgrimage sites in Lourdes, Paris, La Salette, Pontmain, Pompeii, Fatima, Kevelaer, and Knock. ${ }^{131}$ William Bowman has compared pilgrimage to "a type of quest," adding "the grace won for engaging in it ... was supposed to come at the price of physical toil and religious commitment.... Mariazell's relative inaccessibility demanded religious perseverance and increased its popularity." ${ }^{\prime 32}$ With the arrival of the railroad, some of the sanctity that came with inaccessibility was lost. But this change in travel patterns was not unique to Mariazell and cannot explain its relative loss of popularity compared to other Marian shrines in the nineteenth century (nor would Bowman claim that it does). Across Europe, pilgrims took advantage of changing transportation networks to gain easy access to more remote pilgrimage sites, part of a general shift in pilgrimage from dispersed local or regional sites to concentrated, larger, "national" sites. ${ }^{133}$

The most popular pilgrimage sites in the nineteenth century were of relatively recent vintage, they were based on Marian apparitions, and the fortunate ones chosen for such visions were most frequently common folk-in particular women and children. It is possible that it was not Mariazell's putative association with "German" culture, but rather its association with dynastic politics in an age of burgeoning popular religiosity that presented its most grave challenge. In the aftermath of the suspension of the controversial Concordat, even the emperor himself refrained from public displays of religiosity beyond those connected to ceremonial occasions such as the Corpus Christi procession. ${ }^{134}$ In this context, Abel's annual pilgrimages appear not as a sign of nationalist tension but, rather, in the words of John Boyer, as "important new venues for a semi-public Catholicism beyond the confines of everyday church ritual" that "contributed new (and strengthened older) forms of public devotion, as did many Catholic family and especially women's associations that sprang up after 1890-95." 135 In the years before the outbreak of the war, Mariazell had begun to manage the transition from a pilgrimage site whose legitimacy stemmed from imperial (and, of course, papal) favor to one coupled with populist causes-and with touristic appeal.

The editors of Baedeker's guide to the eastern Alps warned in 1879 that, although the town "consists almost entirely of inns and taverns," it was nevertheless "so crowded at the time of the great processions (that of Vienna on $1^{\text {st }}$ July, that of Gratz [sic] on $14^{\text {th }}$ Aug.), and during the

\footnotetext{
processions listed as “öst.," “d. böhm.," "d. ung.," “d. mähr.,” and “stey.” as German-speaking. It is revealing that the recordkeeper used a combination of linguistic and regional designations that cannot possibly be accurately transposed onto national groups. "Stey.", for example, can include both German- and Slovenian-speaking Styrians. I have left out of these calculations the very large (20 percent) group of pilgrims labeled simply as "mähr." or "böhm." without the prefix "d." or "slov." Clearly the thought pattern of the cleric categorizing the pilgrims who arrived in Mariazell does not complement a nationality based historical analysis.

${ }^{130}$ If further proof is needed, it can also be noted that the decrease in visits to Mariazell dated from the beginning of the nineteenth century, long before nationalist conflict became so vociferously proclaimed by interested political parties.

${ }^{131}$ Blackbourn, Marpingen, 4-5, 14-21; on Kevelaer, see Sperber, Popular Catholicism, 64-65.

${ }^{132}$ Bowman, "The State, Popular Religion, and Political Power."

${ }^{133}$ Sperber, Popular Catholicism, 65-66; Christian, Person and God, 49.

${ }^{134}$ Coreth, Pietas Austriaca, 69.

${ }^{135}$ Boyer, Culture and Political Crisis, 166.
} 
latter half of August, that comfortable quarters can rarely be obtained on these occasions." ${ }^{136}$ By 1899, Baedeker's own estimate of annual pilgrims had been reduced from 200,000 to 100,000, but the warning of crowding remained. ${ }^{137}$ Mariazell's troubles, therefore, should not be exaggerated. It is only within the context of the remarkable Marian revival seen in other pilgrimage sites in the nineteenth century that Mariazell's popularity seems low. Given a plethora of alternative, local pilgrimage sites in an era characterized by a putative turning away from the "imperial" toward the "national," the fact that tens of thousands (nearly 100,000 in many years and well over 100,000 in some years) of pilgrims traveled to Mariazell at the turn of the twentieth century could be seen as a great success.

This is not, then, the story of the unbroken march of secularization. ${ }^{138}$ Thanks to Abel's Männer-Wallfahrt, it is not even the story of religion's feminization or retreat into the private sphere. Nor should it be the story of a multinational Austrian pilgrimage site that failed to match the success of a national French one. ${ }^{139}$ On the contrary, the story of Mariazell in the nineteenth century suggests how fluidly modern transportation and entertainment technology, from railroads to photography, could be marshaled in support of the ancient, if malleable, practice of pilgrimage. In Mariazell's embrace of tourism in the late nineteenth century, we see not the triumph of the secular over the sacred but, rather, the attempt to blend harmoniously capitalism, nature tourism, and religion. In the midst of new attention to health, fitness, economic development, the physical environment, and leisure, Mariazell's patrons refused to separate pilgrimage's utility from the pilgrim's pleasure.

Alison Frank is John L. Loeb Associate Professor of the Social Sciences at Harvard University, where she teaches in the history department. The author wishes to thank David Blackbourn, William Bowman, Pieter Judson, Mary Lewis, Mark Mazower, Jonathan Sperber, Judith Surkis, and a particularly dutiful anonymous reader for helpful comments on earlier drafts of this article. She is deeply indebted to Derek Beales, who kindly shared a manuscript chapter of the second volume of his biography of Joseph II. Thanks also to Anna Whittington for brilliant research assistance. Most especially, she is profoundly grateful to P. Benedikt Plank, OSB, at the Stiftsarchiv St. Lambrecht, for his hospitality. Research for this article was supported by grants from the William F. Milton Fund and the American Council of Learned Societies.

\footnotetext{
${ }^{136} \mathrm{~K}$. Baedeker, The Eastern Alps Including the Bavarian Highlands, the Tyrol, Salzkammergut, Styria, and Carinthia, 4th ed. (Leipzig, 1879), 315.

${ }^{137}$ K. Baedeker, The Eastern Alps Including the Bavarian Highlands, Tirol, Salzburg, Upper and Lower Austria, Styria, Carinthia and Carniola, 9th ed. (Leipzig, 1899), 443. The $1888\left(6^{\text {th }}\right)$ edition retains the 200,000 estimate.

${ }^{138}$ Instead, it supports Laurence Cole's contention that the Christian Social movement's "adaptation to modern economic demands occurred in disjunction to cultural acclimatization to modernity." Cole, "The CounterReformation's Last Stand," 310.

${ }^{139}$ Among other problems with setting up Lourdes as a normative standard, to do so disregards the particular context within which Lourdes achieved its special status-a context that could not be reproduced elsewhere at will. As Ruth Harris has argued, "large-scale pilgrimage to Lourdes emerged in response to these shattering events [the Second Empire's collapse following the Franco-Prussian war] and was shaped by the Paris-based Assumptionist Order as part of an overall campaign aimed at nothing less than restoring the Bourbon monarchy, releasing the Pope from his 'Vatican prison,' and re-establishing the alliance between throne and altar." Ruth Harris, Lourdes: Body and Spirit in the Secular Age (New York, 1999), 211.
} 